\title{
Does the Labour Market Explain \\ Lower Female Schooling in India?
}

by

Geeta Gandhi Kingdon*

London Schoool of Economics and University of Oxford

Discussion Paper

DEDPS $/ 1$

January 1997
The Suntory Centre

Suntory and Toyota International Centres for

Economics and Related Disciplines

London School of Economics and Political Science

Houghton Street

London WC2A 2AE

Tel.: 020-7955 6674

* I would like to thank Simon Appleton, Steve Bond, Jean Drèze, John Knight and Francis Teal for their comments on earlier drafts of this paper. Any errors are mine. The institutional support of the Institute of Economics and Statistics, University of Oxford, during the early part of the analysis is gratefully acknowledged.

This research was funded by the Ford Foundation under the project Fiscal Federalism in India, Grant no.940-1021. The data collection for this research and the initial analysis were both funded by a McNamara Fellowship of the World Bank.

NB: This PDF was retrospectively created in June 2002 of the STICERD discussion paper previously known as DERP no.1 which was published in 1997. 


\section{Does the Labour Market Explain Lower Female Schooling in India?}

\section{Abstract}

Labour market discrimination against women and parental discrimination against daughters are two of the most commonly cited explanations of the gender gap in education in developing countries. This study empirically tests the labour market explanation for India using household survey data collected in urban Uttar Pradesh in 1995. It estimates workforce participation functions and selectivity-corrected earnings functions, and calculates the rates of return to education for the two sexes. Using the Blinder-Oaxaca method, the gross gender difference in earnings is decomposed into the part that is explained by men and women's differential characteristics and the part that is due to labour market discrimination. The results reveal that there is substantial omitted family background bias in the estimates of returns and that, contrary to received wisdom, the rates of returns to education rise by education level. The analysis suggests that, as well as overall labour market discrimination, girls face significantly lower economic rates of returns to education than boys.

Keywords: Returns to education; gender; labourforce participation; earnings function; selectivity correction; India.

JEL Nos.: I21, J16, J23, J32, J71.

(C) by Geeta Gandhi Kingdon. All rights reserved. Short sections of text, not to exceed two paragraphs, may be quoted without explicit permission provided that full credit, including (C) notice, is given to the source. 


\section{Introduction}

The social benefits of female education are too well known to require emphasis ${ }^{1}$. It is widely agreed that women's educational backwardness is of concern not only because it is inequitable but also because it is economically and socially inefficient.

In the economics of education literature, two of the most frequently cited explanations of the gender gap in education are parental discrimination against daughters and labour market discrimination against women. This paper examines the latter explanation, that is, that girls may face poorer economic incentives to acquire schooling than boys. This explanation assumes that people acquire education not only for its intrinsic value but also at least partly for its instrumental benefits - including its role in enhancing the labour market earnings of individuals. If the labour market rewards education of different groups differentially, this will affect the perceived economic benefits of education among different groups. Differential labour market returns of males and fernales have been used in the literature to explain not only the gender gap in schooling but also the gender gap in much more fundamental welfare outcomes such as girl and boy survival chances. For example, see Rosenzweig and Schultz (1982) and Bardhan (1987).

This paper examines the labour market for an explanation of the gender gap in education in India, a country that suffers from a well-documented high level of gender-inequality in education, as well as in a number of other measures of welfare, such as girl and boy survival chances, anthropometric measures, and longevity (UNDP 1996). While the gender inequality in education

\footnotetext{
${ }^{\prime}$ Recent research suggests that female schooling is more important than male schooling for social outcomes such as fertility, child health, and infant mortality. See, for example, evidence cited in Strauss and Thomas (1995), King and Hill (1993), Subbarao and Raney (1995), and Murthi, Guio, and Drèze (1996). The literature also suggests that the economic gains from women's education are generally at least as high as those from men's education (see review in Schultz 1993).
} 
is most pronounced in rural India, even in urban India, this gap is significant. For example, in the data for the present study, women had significantly fewer years of education than men at the $1 \%$ level (see Table 12). India, with a Gender Development Index (GDD of 0.410 ranks 103 among the 137 countries for which the GDI has been constructed ${ }^{2}$ (UNDP 1996).

Much of the research on the rates of retum to education in India is dated, using 1970s or pre-70s data. However, the educational structure of wages or the participation of females in the labour force may have changed significantly in the past two decades. Moreover, most existing studies are based on male-only datasets ${ }^{3}$ and many of those that do include females fail to calculate rates separately for males and females. ${ }^{4}$ More importantly, existing research uses conventional methods which may be inappropriate for estimating returns to fernale education since samples of working women may be self-selected ${ }^{5}$. Finally, much of the available research in India is based on the cost benefit method rather than the regression method and it fails to control for the influence, on eamings, of quality of schooling and parental background of individual workers. Schooling picks up the effect of these factors and its impact on earnings is therefore probably overestimated (see, for example, Behrman and Birdsall 1983, Knight and Sabot 1990, and Glewwe 1991). Even in the few, more recent, studies that use the regression method, no controls are employed for parental background and schooling quality.

In India, schooling quality varies very greatly, from impoverished, low quality schools on the one hand, to high-resource schools with world-class achievements on the other. This implies that in the Indian context, number of years of schooling is unlikely to be a good measure of human

\footnotetext{
${ }^{2}$ The GDI attempts to capture achievement through the same set of basic capabilities included in the Human Development Index - life expectancy, educational aftainment, and income -but adjusts the HDI for gender inequality.

${ }^{3}$ For example, Singh (1983), Datta (1985), and review of 10 studies in Tilak (1987, p50).

${ }_{5}^{4}$ See Husain (1969) and Panchmukhi and Panchmukhi (1969). Tilak (1987) and Unni (1995) are exceptions.

${ }^{5}$ Some, though not all, recent studies have used selectivity corrected earnings functions, for example, Duraisany (1988), Malathy (1989), and Unni (1995).
} 
capital acquired. It is important to control for quality of schooling in the earnings functions not only because of this great variation in schooling quality but also because evidence suggests that in India girls face lower quality education than boys. ${ }^{6}$ Parental background of earners may also influence eamings directly - via more influential connections in the job-market - and indirectly, through its association with earners' schooling level. This would lead to an upward bias in the estimate of the rate of return to education and ideally one would wish to isolate this potential omitted variable bias in the earnings function.

The objective here is to estimate rates of return to education separately for men and women, focusing on many interesting issues in the relationship between female education and earnings such as: Do women face lower economic returns to education relative to males in India? In contrast to the norm for many countries, it is estimated that females' retums to schooling rise with the level of schooling in India (Tilak 1987): is this because estimates of returns are capturing the effects of the likely better parental background and quality of education of those females who attain higher education? How significant is the effect of selectivity of working females in the estimation of their returns to education?

We also want to examine the impact of education on women's labour force participation, a subject on which there is little research in India. This research gap is worth filling given that many of the benefits of female education accrue via its role in enhancing women's propensity to work in the labour market. For example, if educated women have higher work aspirations than uneducated women, they may choose lower fertility than uneducated women. Also, a greater proportion of

\footnotetext{
${ }^{6}$ Kingdon (1994 and 1996b) find that boys had a $38 \%$ higher probability than girls of being enrolled in private feecharging schools (which are considered the better quality schools). Drèze and Gazdar (1996) also state that school attendance in private schools in India is significantly male-dominated. Moreover, in Kingdon (1996a, 1996c) girls' achievement in mathematics was significantly lower than that of boys even after controlling for personal and household characteristics, suggesting that they received poorer quality schooling than boys.
} 
women's income is spent on child goods so that, if education enhances women's labour market participation, it may have particular benefits for child quality (see Lockwood and Collier 1988, and Haddad, Hoddinott and Alderman 1994). Further, women's labour force participation appears to be important to poverty reduction in India (Drèze and Srinivasan 1996).

However, in the few empirical studies of women's labour force participation (LFP) in India, there is no consistent evidence of a positive relationship between education of females and their probability of LFP. For example, while Duraisamy (1988) and Nirmala et al (1992) find a negative relationship between women's education and their LFP in rural and urban India respectively, Mathur (1994) finds a U-shaped relationship. Moreover, these studies suffer from certain drawbacks such as non-random samples, use of linear regression rather than a discrete choice model, and using 25 year old, aggregate data rather than recent, individual data ${ }^{7}$. The research here contributes to the scant econometric evidence in India on this important issue, using a method and data that overcome these shortcomings of previous studies.

Section II describes the data and section III the methodology. The choice of labour force participation is modelled in section IV while section $V$ models the impact of education on the labour market earnings of men and women, estimating the private economic rate of retum to education. Section VI applies the Blinder-Oaxaca method to measure the extent of sex discrimination in the labour market. The final section concludes.

\footnotetext{
${ }^{7}$ For example, Nirmala et al's study chose 25 labour force participants and 100 non-labour force participants in urban Pondicherry for the urban LFP equation. Apart from being non-random, the sample is likely to be too small to allow reliable inferences. Duraisamy"s conclusion (p310) that "education of the women is not much rewarding in nural areas and hence it reduces the probability of their participation" is based on the results of a linear probability model, the limitations of which are well known. Duraisany also estimates a probit model of LFP but bases his conclusion on the results of the linear probability model. His probit model shows that education has a significant positive effect on women's LFP. Mathur (1994) uses district level aggregated data on education and LFP from the 1971 census, rather than recent, individual level information from household data.
} 


\section{Data}

The data for this study came from a purpose-designed stratified sample survey of 1000 households in 1995 in Urban Agglomeration of Lucknow district, Uttar Pradesh. The sampling procedure and details of survey instruments and implementation are given in Kingdon (1995). The pre-coded household questionnaire based on the pattern of the World Bank's LSMS studies obtained information not only on personal characteristics and parental background but also on detailed aspects of household members' education, time allocation, and labour market activities, if any. The survey yielded data on 4560 individuals aged 6 years old and over.

Data on labour market activities were collected through questions addressed to all members of sample households between the ages of 15 and 59 years old. The questions pertained to the work force participation and earnings of individuals in the week prior to the survey. Self-reported eamings were recorded for self-employed persons and the focus was on obtaining estimated net earnings rather than gross revenue from sales ${ }^{8}$, as suggested by Vijverberg (1991) based on an evaluation of LSMS data collections of the World Bank. Workers reported earnings for a time-unit of their choice (month, week or day) which were then standardised to an hourly wage using their information on hours worked per day and days worked per week, where relevant. Particular emphasis was placed in the data collection on capturing women's labour market activities since many researchers find that women's work is easily under-enumerated in national sample surveys.

It is possible to compare the occupational distribution of men and women in our survey data from urban Lucknow, with National Sample Survey (NSS) data from urban Uttar Pradesh (UP).

\footnotetext{
${ }^{8}$ Measuring income from family enterprises in household surveys can be a difficult task. While large-scale data collections, such as the LSMS surveys, calculate earnings from self-employment by accounting for all income and expenses in the reference period, this method is very demanding in its requirements. Moreover, evidence suggests that this method may not be supeior to self-reported earnings. For example, as Vijverberg $(1991$, p14) points out, in the Ghanian LSMS data collection in 1986, profits labouriously estimated from detailed data were implausibly negative in 3 out of every 4 family enterprises in commerce and food manufacturing.
} 
The NSS figures in table 1 pertain to the year 1987-88, the latest year, to our knowledge, for which NSS data on employment are available. Table 1 shows that while the occupational distribution of men is strikingly similar in the sample and NSS data, the distribution for women is quite different in the two data sources. In particular, both women's employment and their labour force participation are much lower in NSS data, the latter being about half of the labour force participation rate of women in sample data from Lucknow.

Table 1 Percentage distribution of sample persons aged $15-59$ by main occupation in last 7 days: Comparison of sample data with NSS data

\begin{tabular}{lcccc}
\hline & \multicolumn{2}{c}{ Men } & \multicolumn{2}{c}{ Women } \\
& NSS data & Sample data & NSS data & Sample data \\
\hline Employed (a) & 78.3 & 78.9 & 11.6 & 16.3 \\
Unemployed (b) & 4.5 & 4.7 & 0.4 & 6.0 \\
Labour force participants (c=a+b) & 82.8 & 83.6 & 12.0 & 22.3 \\
Non-participants (d) & 17.2 & 16.4 & 88.0 & 77.7 \\
All persons (e=c+d) & 100.0 & 100.0 & 100.0 & 100.0 \\
\hline
\end{tabular}

Source: NSS data compiled from Table 42 (p16-17) of the UP Report of NSSO(1992). The data are for urban UP and were collected under NSS 43rd Round in 1987-88.

It is possible, even likely, that urban Lucknow - being the capital of UP and one of its largest cities - is more advanced/modem than urban UP so that women's participation in the labour force may be higher there than in urban UP as a whole. A second explanation for the discrepancy between the two data sources is the possibility that women's labour force participation has increased between 1987-88 (reference date for the NSS data in table 1) and 1995 (reference date for the sample data from Lucknow). While these two factors probably explain a part of the large difference in sample and NSS figures on women's employment and work participation, underenumeration of women's work in also an important factor: Nigam (1993, p25) notes that "the accounting of females as workers both in the Census and in NSS suffers from serious enumeration and reporting drawbacks". 


\section{Method}

Education and Labour force participation

While modelling the choice of work force participation is an important exercise in its own right - suggesting the way in which education influences people's participation in the Iabour market

- it is also needed for the consistent estimation of earnings functions for reasons detailed below. Following most applied work, we adopt the standard work force participation model derived from the neo-classical theory of labour supply. Individuals base their decision to participate in the labour market upon their evaluation of a reservation wage, say $E_{r}$, which may be interpreted as the opportunity cost of working or the value put on leisure or on non-market work. Individuals will only enter the labour market if the wage offer $(E)$ exceeds the reservation wage. Thus, working individuals, i.e. individuals for whom wages are observed are those for whom $E>E_{r}$. For non-working persons, $E<=E_{r}$. Let $\Gamma^{*}$ be the net benefit of working. That is,

$$
\Gamma=E-E_{r}
$$

$I$ is a function of a set of variables $W$ which affect either the wage offer or the reservation wage or both. This can be expressed as

$$
I_{i}^{*}=\gamma W_{i}+\varepsilon_{i}
$$

where $\gamma$ is a vector of coefficients and $\varepsilon$ a stochastic disturbance term. As $\Gamma$ is unobserved, we define an indicator variable $I$ such that $I=1$ when an individual is observed to be a labour force participant, and $l=0$ when an individual is not a labour force participant. Thus, individuals are faced with a dichotomous choice: 


$$
\begin{aligned}
& I_{i}=1 \text { if } I_{i}^{*}>0 \Rightarrow \gamma W_{i}+\varepsilon_{i}>0 \\
& I_{i}=0 \text { if } I_{i}^{*} \leq 0 \Rightarrow \gamma W_{i}+\varepsilon_{i} \leq 0
\end{aligned}
$$

Thus, the sample selection rule (SSR) for work force participation is that

$$
\begin{gathered}
r>0 \\
\Rightarrow \quad \gamma W_{i}+\varepsilon_{i}>0 \\
\Rightarrow \quad \varepsilon_{i}>-\gamma W_{i}
\end{gathered}
$$

If it is assumed that $\varepsilon$ is normally distributed with zero mean and unit variance, then the choice between participation or not can be written as a probit model $^{9}$ where the probability of participation is given by

$$
\begin{gathered}
\operatorname{pr}\left(I_{i}=1\right)=\operatorname{pr}\left(I^{*}{ }_{i}>0\right)=\operatorname{pr}\left(\gamma W_{i}+\varepsilon_{i}>0\right) \\
=\operatorname{pr}\left(\varepsilon_{i}>-\gamma W_{i}\right) \\
=\Phi\left(-\gamma W_{i}\right)
\end{gathered}
$$

where $\Phi($.$) is the normal distribution function. This probability can be estimated using maximum$ likelihood methods (see Greene 1993 for a discussion of these methods). Since the choice under consideration is dichotomous - participation or not - a binary formulation of the probit is used.

\section{Education and eamings}

It is desired to estimate the rate of return to education separately for men and women in an unbiased fashion. This involves the correction for sample selection into paid employment. We will employ the standard Mincerian semi-logarithmic earnings function to investigate the determinants of earnings but we modify it to take account of the possibility of sample selection. A simple least squares model of earnings is inadequate if persons for whom earnings are

\footnotetext{
${ }^{9}$ Under alternative assumptions about the distribution of the error term in equation (2), the logit model can also be employed to predict probabilities of work force participation; however, we intend to use the probit model which is the discrete choice model most used in applications of the Heckman correction described in the next section.
} 
observed are not a random draw from the population but a self-selected group. This is plausible if more highly ambitious or motivated persons are more likely to be in the paid work force than persons with lower levels of these unobserved qualities. With self-selected samples, the mean value of the error term in the eamings equation may not equal zero, violating a basic assumption of the classical OLS model. More seriously, the error term may be correlated with the included variables, leading to biased estimates.

In order to correct for the possibility of sample selection we estimate selectivity-corrected earnings functions using the Heckman two step procedure. Let the earnings function be

$$
\operatorname{Ln} Y_{i}=\beta X_{i}+u_{i}
$$

where $\ln Y_{i}$ is the natural log of earnings of the ith worker, $X$ is a vector of variables that influence earnings, $\beta$ is a vector of coefficients and $u$ an error term representing unobserved traits.

However, $\ln Y$ is observed only for individuals who participate in paid work, that is, who are a self-selected or hierarchially selected group ${ }^{\mathrm{I} 0}$. Taking the expectation of $\ln Y$ in equation (6) given the sample selection rule (SSR) in equation (4),

$$
\begin{aligned}
& E\left(\operatorname{Ln} Y_{i} \mid S S R\right)=\beta X_{i}+E\left(u_{i} \mid S S R\right) \\
& E\left(\operatorname{Ln} Y_{i} \mid \varepsilon_{i}>-\gamma W_{i}\right)=\beta X_{i}+E\left(u_{i} \mid \varepsilon_{i}>-\gamma W_{i}\right)
\end{aligned}
$$

\footnotetext{
${ }^{10}$ It is not possible in our model to distinguish between the two reasons for not being in the labour force, namely unemployment and preferences, since their effects are not readily separable. Those people who prefer to work rather than stay at home are 'self-selected'. If there is no full-employment, employers may offer work on the basis of certain traits and attributes of applicants, that is 'hierarchial selection'.
} 
If there is any correlation between the unobserved influences on work participation $\left(\varepsilon_{i}\right)$ and the unobserved influences on earnings $\left(u_{i}\right)$ i.e. if $\operatorname{Corr}\left(\varepsilon_{i}, u_{i}\right) \neq 0$ then $E\left(u_{i} \mid \varepsilon_{i}\right) \neq 0$. Heckman (1979) shows that under the assumption that $\varepsilon_{i}$ and $u_{i}$ are jointly distributed as bivariate normal with zero means, variances $\sigma_{\varepsilon}{ }^{2}$ and $\sigma_{4}{ }^{2}$ and covariance $\sigma_{\mathrm{LE}}$,

$$
E\left(u_{i} l \varepsilon_{i}>-\gamma W_{i}\right)=c \lambda_{i}
$$

where

$$
\lambda_{i}=\phi\left(\gamma W_{i}\right) / \Phi\left(\gamma W_{i}\right)
$$

and

$$
c=\sigma_{u}\left(\sigma_{u \varepsilon} / \sigma_{\varepsilon} \sigma_{\varepsilon}\right)
$$

$\phi($.$) is the standard normal density and \Phi($.$) the normal distribution function. \lambda_{i}$ is the inverse of the Mill's ratio and it is a monotone decreasing function of the probability that an observation is selected into the participants' sub-sample.

Following Heckman (1979), the eamings equation (6) can be corrected for sample selection by estimating $\lambda_{i}$ from the predicted probabilities of the work-participation model, and then including it in (6) so that

$$
\operatorname{Ln} Y_{i}=\beta X_{i}+\alpha \lambda_{i}+v_{i}
$$

where $v_{i}$ is the new error term such that $\mathrm{E}\left(v_{i} \mid \mathrm{SSR}\right)=0$ and $v_{i}$ is uncorrelated with $X$. This method of correcting for sample selectivity has now come to dominate the literature in applications where selected samples are used, such as samples of working women, of migrants, of home owners (rather than renters), of persons who ever enrolled in education etc. We will apply the Heckman correction in our earnings functions by estimating the lambda term from the paid work participation model of the next section. 


\section{Labour force participation}

The analysis here uses the sub-sample of persons aged 15-59 years old who are not students. This is because persons who are in a continuing spell of education cannot be considered as available for work. The dependent variable is participation or not in paid employment (EMPLOY). This includes any kind of salaried employment - whether in the government or private sectors - and any paid self-employment. Unpaid family workers, that is, those working in an enterprise jointly run by household members, are excluded from the category of paid participants ${ }^{11}$. Thus the base or reference category is those not labour force participants, the unemployed, and unpaid workers.

We experimented with two ways of including education in the participation choice model, one with 'education in years' (EDYRS) and the other with education splines that correspond to the main levels of education in India, namely primary, junior, secondary, undergraduate degree, and postgraduate or professional degree. Since the specification with education splines captures nonlinearities in the education-LFP relationship, it was superior in terms of goodness-of-fit measures and we report that as the preferred specification.

To test whether the PWP function differs for the two sexes, a pooled model was estimated with a sex dummy and gender interactions, and is reported in appendix 1. It shows, as expected, that sex is a statistically significant variable with a very large coefficient of -2.154 and suggests that even after controlling for education and other personal characteristics, women are $85 \%$ less likely to

\footnotetext{
${ }^{11}$ Unpaid family workers are excluded since they cannot be included in the estimation of the earnings functions in the next section. Although most family-run enterprises have net income, this cannot be divided up as between working family members on the basis of each workers' marginal productivity. As a result, such persons have been defined as 'unpaid family workers'. Of all working males, $15.1 \%$ were unpaid family workers and of all working females, $19.6 \%$ were unpaid family workers (see table 1 ).
} 
be in the paid labour market than men. The large coefficients and strong statistical significance of many of the gender interaction terms indicated that a pooled model of labour force participation for men and women is highly restrictive.

The parsimonious specification of the probit model estimated separately for men and women is reported in table 4 . Columns 4 and 7 in table 4 show the marginal effect of a unit change in a variable on the probability of PWP, holding all other variables constant at their mean values.Table 2 gives the definitions of variables used in the participation functions and tables $3 a$ and $3 b$ set out the descriptive statistics of those variables for females and males respectively.

\section{Household composition}

Being married has a large and statistically very significant effect on PWP for both men and women. However, the direction of the effect is opposite for the two genders. While being $M A R R I E D$ strongly reduces a woman's chances of being in paid work, it equally strongly increases a man's chances of being in paid work. While marriage brings domestic and home production responsibilities on females, it magnifies the economic responsibilities of males in the household.

Being the $H E A D$ of the household very significantly increases the propensity to do paid work for both men and women. This is consistent with the notion of economic responsibility falling mainly on household heads. For women, headship is associated with a $20 \%$ greater probability of being a paid worker compared with women who are not head of household. For men, the effect is $16 \%$. 
Table 2 Definitions of variables used in the paid-work participation and earnings functions

\begin{tabular}{|c|c|}
\hline Variable & Description \\
\hline EMPLOY & $\begin{array}{l}\text { Participated in paid employment in past } 7 \text { days? yes }=1, \text { no }=0 \text { (also referred to as paid work } \\
\text { participation or PWP) }\end{array}$ \\
\hline$L O G Y 7$ & Natural log of hourly earnings \\
\hline$A G E$ & Age in years \\
\hline AGESQ & Square of $A G E$ \\
\hline MAWORKED & Did mother ever work in an income-generating activity? yes $=1$, no $=0$ \\
\hline PAEDYRS & Father's education in years \\
\hline PAWEAL & Index of parental wealth, based on assets owned by the respondent's family when a child \\
\hline MARRIED & Ever married? yes $=1, \mathrm{no}=0$ \\
\hline$H E A D$ & Head of household? yes $=1$, no $=0$ \\
\hline NCHILDI4 & Number of children below age 14 years in household \\
\hline DCENTRE & Distance in kilometers from home to Lucknow city centre \\
\hline HEAL7 & Index of health in past 7 days, good $=1$, satisfactory $=2$, unsatisfactory $=3$, bad $=4$ \\
\hline MUSLIM & Religion Muslim? yes $=1$, no $=0$ \\
\hline LOWCASTE & Belongs to a low or backward caste? yes $=1$, no $=0$ \\
\hline PRIMARY & Gained 1 to 5 years of education? yes $=1$, no $=0$ \\
\hline JUNIOR & Gained 6 to 9 years of education? yes $=1$, no $=0$ \\
\hline SECONDAR & Gained 10 to 12 years of education? yes $=1$, no $=0$ \\
\hline$B A C H E L O R$ & Gained 13 to 15 years of education? yes $=1$, no $=0$ \\
\hline MASTERS & Gained $>=16$ years of education? yes $=1$, no $=0$ \\
\hline PROF & Gained a professional degree? yes $=1, n 0=0$ \\
\hline TRAINING & Gained vocational training? yes $=1$, no $=0$ \\
\hline EXPER & Years of work experience \\
\hline EXPERSQ & Square of $E X P E R$ \\
\hline WCOLLAR & Works in a white collar occupation? yes $=1$, no $=0$ \\
\hline UNION & Belongs to a unionised group of workers? yes $=1$, no $=0$ \\
\hline GOVT & Works in the government sector? yes $=1$, no $=0$ \\
\hline$S I Z E$ & Number of employees in individual's workplace \\
\hline WORKHOME & Works at home? yes $=1$, no $=0$ \\
\hline EDYRS & Years of education acquired \\
\hline$\angle A M B D A$ & Selectivity term, inverse of Mill's Ratio \\
\hline
\end{tabular}


Table 3a Descriptive statistics of variables used in the paid-work participation function

FEMALES

\begin{tabular}{|c|c|c|c|c|c|c|}
\hline \multirow[t]{2}{*}{ Variable } & \multicolumn{2}{|c|}{$\begin{array}{c}\text { Non-participants in paid } \\
\text { employment }\end{array}$} & \multicolumn{2}{|c|}{$\begin{array}{c}\text { Participants in paid } \\
\text { employment }\end{array}$} & \multicolumn{2}{|c|}{ All } \\
\hline & Mean & SD & Mean & SD & Mean & SD \\
\hline EMPLOY* & 0.000 & 0.00 & 1.000 & 0.00 & 0.1453 & 0.35 \\
\hline$A G E$ & 34.224 & 11.18 & 34.603 & 11.14 & 34.279 & 11.17 \\
\hline AGESQ & 1296.200 & 810.63 & 1320.800 & 818.60 & 1299.800 & 811.52 \\
\hline MAWORKED* & 0.142 & 0.49 & 0.365 & 0.74 & 0.175 & 0.54 \\
\hline PAEDYRS & 0.7032 & 5.74 & 7.005 & 6.10 & 7.028 & 5.79 \\
\hline PAWEAL & 8.357 & 6.79 & 8.450 & 6.92 & 8.370 & 6.81 \\
\hline MARRIED* & 0.858 & 0.35 & 0.757 & 0.43 & 0.843 & 0.36 \\
\hline$H E A D^{*}$ & 0.032 & 0.18 & 0.143 & 0.35 & 0.048 & 0.21 \\
\hline NCHILDI4 & 1.292 & 1.43 & 0.995 & 1.37 & 1.249 & 1.43 \\
\hline$D C E N T R E$ & 7.083 & 4.86 & 7.328 & 4.90 & 7.118 & 4.87 \\
\hline HEAL7 & 1.141 & 0.45 & 1.101 & 0.33 & 1.135 & 0.44 \\
\hline LOWCASTE* & 0.287 & 0.45 & 0.376 & 0.49 & 0.300 & 0.46 \\
\hline PRIMARY* & 0.097 & 0.30 & 0.085 & 0.30 & 0.095 & 0.29 \\
\hline JUNIOR* & 0.163 & 0.37 & 0.042 & 0.20 & 0.145 & 0.35 \\
\hline$S E C O N D A R^{*}$ & 0.244 & 0.43 & 0.143 & 0.35 & 0.229 & 0.42 \\
\hline BACHELOR* & 0.133 & 0.34 & 0.190 & 0.39 & 0.141 & 0.35 \\
\hline MASTERS* & 0.085 & 0.28 & 0.217 & 0.41 & 0.104 & 0.31 \\
\hline PROF* & 0.008 & 0.09 & 0.026 & 0.16 & 0.011 & 0.10 \\
\hline EDYRS & 7.954 & 5.98 & 9.328 & 7.12 & 8.154 & 6.17 \\
\hline TRAINING* & 0.118 & 0.32 & 0.291 & 0.46 & 0.143 & 0.35 \\
\hline$N$ & 111 & & 18 & & 130 & \\
\hline
\end{tabular}

Note: The variables with superscript * are $0 / 1$ variables, so that their means represent the proportion of ones in the sample. 
Table 3b Descriptive statistics of variables used in the paid-work participation function MALES

\begin{tabular}{|c|c|c|c|c|c|c|}
\hline \multirow[t]{2}{*}{ Variable } & \multicolumn{2}{|c|}{$\begin{array}{c}\text { Non-participants in paid } \\
\text { employment }\end{array}$} & \multicolumn{2}{|c|}{$\begin{array}{c}\text { Participants in paid } \\
\text { employment }\end{array}$} & \multicolumn{2}{|c|}{ AII } \\
\hline & Mean & SD & Mean & SD & Mean & SD \\
\hline$E M P L O Y^{*}$ & 0.000 & 0.00 & 1.000 & 0.00 & 0.771 & 0.42 \\
\hline$A G E$ & 31.100 & 12.67 & 35.558 & 11.02 & 34.537 & 11.57 \\
\hline$A G E S Q$ & 1127.300 & 910.59 & 1385.6 & 813.29 & 1326.500 & 843.24 \\
\hline MAWORKED* & 0.208 & 0.57 & 0.207 & 0.59 & 0.207 & 0.59 \\
\hline PAEDYRS & 6.588 & 5.58 & 6.824 & 5.63 & 6.769 & 5.62 \\
\hline PAWEAL & 10.856 & 8.85 & 7.909 & 6.33 & 8.584 & 7.09 \\
\hline$M A R R I E D^{*}$ & 0.503 & 0.50 & 0.780 & 0.41 & 0.717 & 0.45 \\
\hline$H E A D^{*}$ & 0.291 & 0.45 & 0.572 & 0.49 & 0.508 & 0.50 \\
\hline NCHILDI4 & 0.726 & 1.29 & 1.256 & 1.42 & 1.135 & 1.41 \\
\hline DCENTRE & 7.047 & 5.07 & 7.043 & 4.69 & 7.044 & 4.78 \\
\hline$H E A L 7$ & 1.110 & 0.45 & 1.058 & 0.29 & 1.070 & 0.33 \\
\hline LOWCASTE* & 0.325 & 0.47 & 0.314 & 0.46 & 0.317 & 0.47 \\
\hline PRIMARY* & 0.066 & 0.25 & 0.084 & 0.28 & 0.080 & 0.27 \\
\hline JUNIOR* & 0.213 & 0.41 & 0.148 & 0.36 & 0.163 & 0.37 \\
\hline$S E C O N D A R^{*}$ & 0.313 & 0.46 & 0.273 & 0.45 & $0.28 \mathrm{I}$ & 0.45 \\
\hline$B A C H E L O R^{*}$ & 0.153 & 0.36 & 0.208 & 0.41 & 0.196 & 0.40 \\
\hline MASTERS* & 0.022 & 0.15 & 0.078 & 0.27 & 0.065 & 0.25 \\
\hline PROF* & 0.053 & 0.22 & 0.102 & 0.30 & 0.091 & 0.29 \\
\hline EDYRS & 8.959 & 5.36 & 10.696 & 5.45 & 10.298 & 5.48 \\
\hline$T R A I N I N G^{*}$ & 0.056 & 0.23 & 0.129 & 0.34 & 0.112 & 0.32 \\
\hline$N$ & 32 & & & & 13 & \\
\hline
\end{tabular}

Note: The variables with superscript * are $0 / 1$ variables, so that their means represent the proportion of ones in the sample. 
Table 4 Binary probit estimates of paid-work participation, by gender

\begin{tabular}{|c|c|c|c|c|c|c|}
\hline \multirow[t]{2}{*}{ Variable } & \multicolumn{3}{|c|}{ Women } & \multicolumn{3}{|c|}{ Men } \\
\hline & coefficient & t-value & $\begin{array}{c}\text { marginal } \\
\text { effect }\end{array}$ & coefficient & t-value & $\begin{array}{c}\text { marginal } \\
\text { effect }\end{array}$ \\
\hline Intercept & -1.8106 & $-3.12^{* * *}$ & -0.339 & -0.2516 & -0.52 & -0.070 \\
\hline$A G E$ & 0.0678 & $1.93^{*}$ & 0.013 & 0.0535 & $1.83^{*}$ & 0.015 \\
\hline$A G E S Q$ & -0.0008 & $-1.80 *$ & -0.000 & -0.0010 & $-2.62^{* * *}$ & -0.000 \\
\hline$M A W O R K E D$ & 0.3111 & $4.07^{* * *}$ & 0.058 & 0.0964 & 1.33 & 0.027 \\
\hline PAEDYRS & -0.0356 & $-2.69^{* * *}$ & -0.007 & 0.0066 & 0.67 & 0.002 \\
\hline$P A W E A L$ & -0.0135 & -1.43 & -0.003 & -0.0309 & $-4.47^{* * * *}$ & -0.009 \\
\hline MARRIED & -0.6152 & $-3.53 * * *$ & -0.115 & 0.4491 & $3.18^{* * *}$ & 0.124 \\
\hline$H E A D$ & 1.0509 & $5.74^{* * *}$ & 0.197 & 0.5818 & $4.76^{* * *}$ & 0.161 \\
\hline NCHILDI4 & -0.0443 & -0.99 & -0.008 & -0.0225 & -0.58 & -0.006 \\
\hline DCENTRE & 0.0069 & 0.72 & 0.001 & -0.0156 & $-1.84^{*}$ & -0.004 \\
\hline$H E A L 7$ & -0.1262 & -1.06 & -0.024 & -0.1866 & -1.64 & -0.052 \\
\hline LOWCASTE & 0.2466 & $2.18^{* *}$ & 0.046 & 0.0292 & 0.31 & 0.008 \\
\hline PRIMARY & -0.0129 & -0.07 & -0.002 & 0.5481 & $3.11^{* * *}$ & 0.152 \\
\hline JUNIOR & -0.5172 & $-2.54 * * *$ & -0.097 & 0.2765 & $1.92 *$ & 0.076 \\
\hline SECONDAR & 0.0553 & 0.32 & 0.010 & 0.2897 & $2.01 *$ & 0.080 \\
\hline$B A C H E L O R$ & 0.6279 & $2.93^{* * *}$ & 0.118 & 0.6230 & $3.50^{* * *}$ & 0.172 \\
\hline MASTERS & 0.9758 & $4.06^{* * *}$ & 0.183 & 1.0445 & $3.96^{* * *}$ & 0.289 \\
\hline PROF & 1.3324 & $3.29^{* * *}$ & 0.250 & 0.8330 & $3.83^{* * *}$ & 0.230 \\
\hline TRAINING & 0.4465 & $3.38^{* * *}$ & 0.084 & 0.3730 & $2.43^{* * *}$ & 0.103 \\
\hline $\log L$ & . & -451.87 & & & 33 & \\
\hline Restricted Log L & & -537.74 & & & .71 & \\
\hline Psuedo $R^{2}$ & & 0.160 & & & & \\
\hline
\end{tabular}

Note: $* * *$ and $* * *$ represent significance at the $10 \%, 5 \%$, and $1 \%$ levels respectively. The marginal effects are evaluated at the sample means of the variables. The base or reference category is non-participation in paid work. McFadden's psuedo $R^{2}$ is calculated as $1-\left(L n L / n n L_{0}\right)$, where $L n L$ is the maximum of the $\log \operatorname{likelihood~function~and~}$ $L_{n} L_{0}$ is the restricted $\log$ likelihood, that is when the model is estimated with just the constant term (Maddala 1989). 
Number of children below age 14 years $(N C H L L 14)$ is not a significant deterninant of the choice of PWP. It is noted by a number of studies (for example, Behrman and Wolfe 1984, and Appleton, Collier, and Horsnell 1990 inter alia) that while Iabour force participation is usually inversely related to fertility in industrial countries, this is often not the case in developing countries. In India, the extended family structures still prevalent would seem to absorb the burden of childcare. That the presence of children does not significantly inhibit women's PWP may also reflect that staying at home with one's children is an activity which very poor women cannot afford ${ }^{12}$.

\section{Personal variables}

There is a significant quadratic effect in $A G E$ for both men and women. PWP increases with age but at a decreasing rate, peaking at age 40 for women and at age 27 for men. Low and backward caste (LOWCASTE) women are significantly more likely to be in paid employment than high caste women but caste is orthogonal to men's participation decision. The effect of caste on women's PWP is consistent with the suggestion that in India, lowcaste women can work without scom or disapproval from their kin-group but that caste norms dictate that upper caste women may not work without risk of censure. Chen and Drèze (1992) give a similar explanation for their finding that in India, high caste widows are more deprived than low caste widows since they are caught between the contradictory demands of survival and 'sanskritization', that is, the need to maintain their caste/social status.

\section{Parental variables}

A female whose mother ever worked in the labour market is very significantly more likely to participate in paid work than one whose mother never worked, though this variable is immaterial

\footnotetext{
${ }^{12}$ As Murthi, Guio, and Drèze (1996) point out, "female labour force participation in India is often a reflection of economic hardship".
} 
to the male PWP. The pooled model in Appendix 1 shows that the marginal effect of the gender interaction with $M A W O R K E D$ is 0.104 , suggesting that women whose mothers worked are $10.4 \%$ more likely to work for pay than men whose mothers worked.

The negative sign on the parental education variable (PAEDYRS) in the female equation suggests an economic rather than an educational interpretation: PAEDYRS appears to proxy for parents' economic status since the parental wealth variable PAWEAL is likely to be imperfectly measured. In the male equation, PAWEAL performs a similar role as PAEDYRS does in women's equation, namely that persons who have affluent parents are less likely to be in paid work than people from poor homes, ceteris paribus. This is plausible because such persons may evaluate higher reservation wages or be financially more able to wait for a well-paying job.

\section{Education and training}

Possession of any form of vocational training in crafts, tailoring, repairs or electrical work, etc. significantly increases the chances of being gainfully employed for both the sexes. Women with training are $8 \%$ more likely to work gainfully than women without training. The corresponding figure for men is similar at $10 \%$.

For men the relationship between education and the probability of PWP is approximately linear, except for a blip at primary education ${ }^{13}$. For women, education has a distinctly U-shaped relationship with participation in paid employment: the coefficients on the education 'dummies' first fall and then rise monotonically, suggesting that the probability of being in paid work furst

\footnotetext{
${ }^{13}$ That men's PWP increases with education appears surprising but may be explained in the following 2 ways: firstly, employers may ration appointments by education level of worker, so that the most well educated have the greatest chance of being employed; secondly, among the men who work, those with higher levels of education may opt to be in work independently of their farnily but men with low levels of education may be more likely to work in unpaid family employment.
} 
decreases up to junior level education but then increases sharply with further levels of education ${ }^{14}$. Women with junior level education are $10 \%$ less likely to be in paid work than women with no education; Compared with women who have junior level education, secondary certificate holders are $12 \%$ more likely to be gainfully employed. Similarly, bachelor's degree holders are $22 \%$, postgraduates $28 \%$, and professional degree holders $35 \%$ more likely to be in paid work than women with junior education, holding all other variables constant at their mean values.

An explanation for the downward part of the U-shaped relationship between education and work participation may lie in the 'sanskritization' hypothesis alluded to earlier (see Chen and Drèze 1992): Just as it is socially more acceptable for lowcaste women to work than for high caste women, in the same way, women with no education may work while those with some low levels of education may not want to lessen their social standing by doing labour market work. However, sanskritization does not explain why highly educated women are more likely to participate in paid work than women with low or no education. The answer may lie in one or more of the following observations:

(i) if rates of return to education rise with education level, then those with high levels of education will have stronger economic incentives to work than those with low or no education. The results of the next section - which show negative or (insignificantly different to) zero returns to women's primary and junior education and significant positive returns to their secondary and higher education (see tables 8 and $9 \mathrm{~b}$ ) - provide support for this explanation,

(ii) high levels of education have a modernising influence and they change women's ambitions and work aspirations, perhaps lowering their reservation wage, and

(iii) women who opt for high levels of education are a self-selected group, perhaps coming from progressive families where attitudes to women's work are favourable; however, the fact that we have included three parental background variables in the model - two of which are highly

\footnotetext{
${ }^{14}$ Unni (1995) also finds a U-shaped relationship between education and PWP for women, and interestingly also for men, both in Madhya Pradesh and Tanil Nadu.
} 
significant in the women's regression - weakens this potential interpretation, though it is arguable that parents' background is still only imperfectly measured.

In conclusion, women and men have markedly different rates of participation in paid employment and a large gap in participation rate remains even after controlling for education and other characteristics. This appears not to be due to the burden of child-care. A likely explanation is Indian women's deep-seated beliefs about their gender-role in society which shape their work aspirations. Another likely explanation, and one which is tested in section VI, is that women face labour market discrimination which dampens their inclination to do paid work.

\section{Earnings in the labour market}

The purpose of the analysis here is to investigate whether the economic incentives to acquire education vary by gender, that is, whether the private rates of return to education are different for the two sexes. Table 2 defined the variables used in the earnings functions and table 5 presents their means and standard deviations. The dependent variable is the natural log of hourly earnings, LOGY7.

We present 2 specifications of the eamings functions, one a pure Mincerian specification, that is with just education, experience, and experience-square (tables 6 and 7), and the second an extended earnings function which includes a number of variables other than schooling and experience, such as caste, religion, marriage status, and job characteristics (table 10). Table 6 uses 'years of schooling' or EDYRS and table 7 uses education level dummies (primary, junior, secondary, bachelor, masters, and professional) to capture non-linearities in the relationship 
between education and earnings ${ }^{\text {ts; }}$, each of the specifications is presented with and without the family background variable $P A E D Y R S$.

Note that the measure of years of experience (EXPER) here is calculated as 'age less age at which started labour market work'. This is better than the 'age less age at which left school' measure used in most studies, in that our measure allows for the fact that not all people start work immediately after completing schooling. This is particularly important when measuring work experience for women - who often delay work force participation until after child-bearing and rearing years ${ }^{16}$. However, despite this benefit, our measure does not capture the intensity of work experience since for the same measured number of years of experience, men are likely to have greater hours of experience and learning-by-doing than women, as many women work part time or intermittently.

\footnotetext{
${ }^{15}$ The education dummies of primary, junior, and secondary include grades 1 to 5 , grades 6 to 9 , and grades 10 to 12 respectively. The other dummies are bachelor's degree, master's degree, and professional degree (mainly engineering, medicine, and law). Note that although the junior cycle normally consists of 3 years, we have included grade 9 as belonging to the junior cycle since there were very few observations with grades 6 to 8 in the sample of working women. This is reasonable if recruitment is based on (or returns accrue to) the completion of high school (ie class 10 ) and not to the completion of class 9 , as is likely.

${ }^{16}$ Section IV showed that women's labour force participation peaks at age 40 and men's at age 27 , suggesting that many women start work late, for example up to their late 30 s, so that it is important to allow for late starting. A comparison between the two measures of experience - the ususal one based on school leaving age $(E X P)$ and one based on age at which started work $(E X P E R)$ - is helpful in gauging the accuracy of our preferred measure. The mean value of EXP is 20.5 years for women and 18.8 years for men but the mean value of $E X P E R$ is only 10.6 years for women and 16.0 years for men, suggesting that our preferred measure (EXPER) is good at allowing for time out of work.
} 
Table 5 Descriptive statistics of variables used in the earnings functions

\begin{tabular}{|c|c|c|c|c|}
\hline \multirow[t]{2}{*}{ Variable } & \multicolumn{2}{|c|}{ Women } & \multicolumn{2}{|c|}{ Men } \\
\hline & Mean & SD & Mean & SD \\
\hline$\overline{L O G Y 7}$ & 1.7486 & 1.08 & 2.3156 & 0.94 \\
\hline EXPER & 10.5580 & 9.43 & 16.027 & 10.83 \\
\hline EXPERSQ & 199.8800 & 303.35 & 374.0900 & 410.33 \\
\hline LOWCASTE & 0.3757 & 0.49 & 0.3244 & 0.47 \\
\hline MUSLIM & 0.1437 & 0.35 & 0.1429 & 0.35 \\
\hline WCOLLAR & 0.5304 & 0.50 & 0.4405 & 0.50 \\
\hline UNION & 0.2541 & 0.44 & 0.3800 & 0.49 \\
\hline GOVT & 0.3260 & 0.47 & 0.4127 & 0.49 \\
\hline$S I Z E$ & 37.3700 & 72.16 & 80.3130 & 101.94 \\
\hline WORKHOME & 0.2099 & 0.41 & 0.0248 & 0.16 \\
\hline MARRIED & 0.7514 & 0.43 & 0.7877 & 0.41 \\
\hline EDYRS & 9.3094 & 7.13 & 10.6590 & 5.53 \\
\hline TRAINING & 0.2818 & 0.45 & 0.1310 & 0.34 \\
\hline NO EDUCATION* & 0.2984 & 0.46 & 0.1100 & 0.33 \\
\hline PRIMARY & 0.0829 & 0.28 & 0.0873 & 0.28 \\
\hline JUNIOR & 0.0442 & 0.21 & 0.1478 & 0.36 \\
\hline$S E C O N D A R$ & 0.1381 & 0.34 & 0.2639 & 0.44 \\
\hline BACHELOR & 0.1989 & 0.40 & 0.2054 & 0.40 \\
\hline MASTERS & 0.2099 & 0.41 & 0.0814 & 0.27 \\
\hline PROF & 0.0276 & 0.16 & 0.1042 & 0.31 \\
\hline PAEDYRS & 7.0221 & 6.14 & 6.7629 & 5.55 \\
\hline$\angle A M B D A$ & 1.3113 & 0.43 & 0.3354 & 0.22 \\
\hline $\mathbf{N}$ & 182 & & 1009 & \\
\hline
\end{tabular}

Note: *No education is the base category in the earnings functions where education is specified as a series of categorical or dummy variables. 
Table 6 Mincerian earnings functions, with $E D Y R S$

\begin{tabular}{|c|c|c|c|c|}
\hline \multirow[t]{2}{*}{ Variable } & \multicolumn{2}{|c|}{$\overline{\text { Men }}$} & \multicolumn{2}{|c|}{ Women } \\
\hline & Equation 1 & Equation 2 & Equation 1 & Equation 2 \\
\hline Intercept & $\begin{array}{r}0.5235 \\
(4.89)^{* * *}\end{array}$ & $\begin{array}{r}0.5143 \\
(4.88)^{* * *}\end{array}$ & $\begin{array}{r}0.3204 \\
(1.18)\end{array}$ & $\begin{array}{l}0.4773 \\
(1.79)^{*}\end{array}$ \\
\hline EXPER & $\begin{array}{c}0.0703 \\
(9.34)^{* * *}\end{array}$ & $\begin{array}{r}0.0744 \\
(10.00)^{* * *}\end{array}$ & $\begin{array}{c}0.1019 \\
(4.97)^{* * *}\end{array}$ & $\begin{array}{r}0.0979 \\
(4.92)^{* * *}\end{array}$ \\
\hline EXPERSQ & $\begin{array}{c}-0.0012 \\
(-6.08)^{* * *}\end{array}$ & $\begin{array}{r}-0.0013 \\
(-6.50)^{* * *}\end{array}$ & $\begin{array}{r}-0.0023 \\
(-3.60)^{* * *}\end{array}$ & $\begin{array}{r}-0.0021 \\
(-3.38)^{* * *}\end{array}$ \\
\hline EDYRS & $\begin{array}{r}0.1059 \\
(26.60)^{* * *}\end{array}$ & $\begin{array}{r}0.0892 \\
(18.37)^{* * *}\end{array}$ & $\begin{array}{r}0.0955 \\
(10.69)^{* * *}\end{array}$ & $\begin{array}{r}0.0490 \\
(3.05)^{* * *}\end{array}$ \\
\hline PAEDYRS & & $\begin{array}{r}0.0257 \\
(5.83)^{* * * *}\end{array}$ & & $\begin{array}{r}0.0633 \\
(3.44)^{* * *}\end{array}$ \\
\hline$\angle A M B D A$ & $\begin{array}{r}-0.0815 \\
(-0.67)\end{array}$ & $\begin{array}{r}-0.1712 \\
(-1.41)\end{array}$ & $\begin{array}{r}-0.0668 \\
(-0.46)\end{array}$ & $\begin{array}{r}-0.1929 \\
(-1.31)\end{array}$ \\
\hline $\begin{array}{l}\text { Adjusted } \\
\text { R-Square }\end{array}$ & 0.5658 & 0.5796 & 0.4257 & 0.4588 \\
\hline Dependent & $\begin{array}{r}1009 \\
2.3163\end{array}$ & $\begin{array}{r}1009 \\
2.3163\end{array}$ & $\begin{array}{r}182 \\
1.7390\end{array}$ & $\begin{array}{r}182 \\
1.7390\end{array}$ \\
\hline
\end{tabular}

Results

Before examining the results of the estimated earnings functions, note the mean and variation in the dependent variable $L O G Y 7$. Table 5 shows that expressed in logs, the average hourly earnings of men are about $32 \%$ higher than those of women. Women's earnings are both lower and have more dispersion than men's.

Observe equation 1 in table 6. Experience and its quadratic (EXPER and EXPERSQ) have a strong and significant effect on earnings for both men and women, confirming the expected concavity: earnings increase with on-the-job training and 'learning-by-doing' but do so at a decreasing rate. Schooling has a highly significant effect on earnings and the premium for each 
extra year of schooling is about $10.6 \%$ for men and $9.6 \%$ for women. In other words, the Mincerian rate of return to education is modest at about $10 \%$ and is somewhat lower for women than for men.

Next focus on equation 2 in table 6 . This includes family background as measured by father's education in years (PAEDYRS). We stated earlier that in India, schooling quality and children's out-of-school human capital accumulation vary greatly so that years of education is not a good measure of human capital acquired. We tried two proxies for schooling quality and out-ofschool human capital acquisition: (a) family background, since schooling quality varies much by family background in India $^{17}$ and out-of-school learning is also plausibly linked with home background, and (b) achievement test score of the worker. Unfortunately, there were many missing values for achievement scores since not all of the respondents took the achievement tests in maths and reading ${ }^{18}$. As a result, we have used family background as our preferred proxy.

With the inclusion of family background, the rate of return to education falls to $8.9 \%$ for men and $4.9 \%$ for women, suggesting that there is considerable omitted variable bias in the estimates of rates of return to education. Controlling for personal human capital and parental background, women's returns to education are $45 \%$ lower than men's, a difference that is large and statistically significant ${ }^{19}$. This sizeable gender asymmetry in returns suggests that females have much poorer labour market incentives to acquire education than males in urban India.

\footnotetext{
${ }^{17}$ Kingdon (1996a) found that parental background was significant in explaining the type of school attended by a child and schooling quality varied by type of school attended (government school, aided private school, or feecharging private school). Background was also highly important in explaining student achievement (another measure of schooling quality).

${ }^{18}$ When we use achievement test scores, the number of observations in the regression drops to 141 women and 555 men, implying a loss of 505 observations. In earnings functions fitted with achievement score as an explanatory variable, the rate of retum to education is $4.8 \%$ or women and $7.0 \%$ for men, implying that women's returns are $31 \%$ lower than men's returns.

"A wald test shows a chi-squared statistic of 5.74 while the critical chi-square (1) at the $95 \%$ level is 3.84 . Thus, the null hypothesis that male and female returns to education are equal is rejected. That the gender difference in returns is significant is also confirmed by a pooled model of males and females with education, experience,
} 
Women's returns to education are much more sensitive to family background than men's suggesting that girls' out-of-school investment in leaming and their quality of education are more dependent on family's background than boys'. This is plausible since in a society where boys' education appears to be given more importance than girls ${ }^{20}$, only the educationally oriented families are likely to emphasise daughters' educational attainment and quality of education, but most parents - whether educationally oriented or not - tend to emphasise boys' good education.

Our interpretion that the coefficient on PAEDYRS reflects aspects of quality of education and out-of-school investments in education (such as private home tuition or help with leaming in the home) is in line with that in Heckman and Hotz (1986). However, it is possible that the significance of PAEDYRS reflects retums to family connections and nepotism, as suggested by Lam and Schoeni (1993) for Brazil. However, if that were the case in our data, we would expect the effect of PAEDYRS to be greater for males, as parents in poor countries are generally more concerned about sons' employment and would try harder to use influence to promote sons' entry into better jobs.

While we do not claim an unambiguous interpretation for the effect of PAEDYRS, it is clear that omitted family background bias exists and is substantial: about $16 \%$ for men and $49 \%$ for women. This corroborates the findings of Behrman and Wolfe (1984), Heckman and Hotz (1986)

experience square, parental background, and each of the variables interacted with gender. This regression show that the EDYRS-gender interaction term is significant at the $1 \%$ level.

${ }^{20}$ For example, Kingdon (1994) finds that in urban Uttar Pradesh, after controlling for family's educational and economic background, caste, and religion, boys had a $38 \%$ higher probability than girls of attending the fee-charging private schools which are considered to be the better quality schools. Also, average per pupil household expenditure on education was higher for boys than girls. In the present household dataset, annual per pupil household educational expenditure for those currently enrolled in classes 1 to 12 is Rs. 1080 for boys and Rs. 871 for girls. That is, educational expenditure on boys is about $25 \%$ more than on girls. Moreover, while $33 \%$ of all male students take private home tuitions, only $23 \%$ of girls do. These observations and figures suggest that in India, the education of male offspring is given greater importance than that of female children. 
and Lam and Schoeni (1993) on Nicaragua, Panama, and Brazil respectively; these studies report that returns to education fall by between $25 \%$ and $33 \%$ when family background is included in the eamings function. It suggests that studies that ignore home background may substantially overestimate the rate of return to education.

\section{Is the rate of retum greatest for primary education?}

Next, consider the nature of the relationship between education and earnings by observing the coefficients on the education dummies in table 7 . The inclusion of the family background measure PAEDYRS in equation 2 significantly reduces the returns to higher education in both male and female regressions: a series of wald tests show that when family background is included, only the returns to post-secondary education levels fall significantly (at the $5 \%$ level) ${ }^{21}$. This suggests that men and women who acquire higher education come from privileged backgrounds and a significant part of their return to education is due to their better background. A pure Mincerian specification of the earnings function exaggerates the estimated retums only of higher education.

Table 8 reports the rates of return to each year of an education cycle ${ }^{22}$ estimated from table 7. It suggests that the rate of return to education generally rises with education level. Indeed, for the primary level, the rate of return is insignificantly different from zero for both men and women and this is also the case at the junior level for women.

\footnotetext{
${ }^{21}$ The wald statistics for bachelor, masters, and prof were $4.2,4.9$, and 2.2 for women and $4.8,3.1$, and 4.0 for men. For primary, junior, and secondary education levels the wald statistics were below 1.2 for both men and women.

${ }^{22}$ The marginal rate of return to each year of education at, say secondary level, is calculated by subtracting the coefficient on JUNIOR from the coefficient on SECONDAR and then dividing the result by the number of years in the secondary cycle, that is by 3 years.
} 
Table 7 Mincerian Earnings fonction, with education splines

\begin{tabular}{|c|c|c|c|c|}
\hline \multirow[t]{2}{*}{ Variable } & \multicolumn{2}{|c|}{ Men } & \multicolumn{2}{|c|}{ Women } \\
\hline & Equation 1 & Equation 2 & Equation 1 & Equation 2 \\
\hline Intercept & $\begin{array}{r}0.7314 \\
(6.01)^{* * *}\end{array}$ & $\begin{array}{r}0.7118 \\
(5.94)^{* * *}\end{array}$ & $\begin{array}{r}0.3219 \\
(1.15)\end{array}$ & $\begin{array}{l}0.5015 \\
(1.80)^{*}\end{array}$ \\
\hline EXPER & $\begin{array}{r}0.0707 \\
(9.31)^{* * *}\end{array}$ & $\begin{array}{r}0.0748 \\
(9.97)^{* * *}\end{array}$ & $\begin{array}{r}0.1019 \\
(4.86)^{* * *}\end{array}$ & $\begin{array}{r}0.1020 \\
(4.99)^{* * *}\end{array}$ \\
\hline EXPERSQ & $\begin{array}{r}-0.0012 \\
(-6.11)^{* * *}\end{array}$ & $\begin{array}{r}-0.0012 \\
(-6.52)^{* * *}\end{array}$ & $\begin{array}{r}-0.0023 \\
(-3.50)^{* * *}\end{array}$ & $\begin{array}{r}-0.0023 \\
(-3.52)^{* * *}\end{array}$ \\
\hline PRIMARY & $\begin{array}{r}0.1293 \\
(1.41)\end{array}$ & $\begin{array}{r}0.0692 \\
(0.76)\end{array}$ & $\begin{array}{r}-0.1583 \\
(-0.66)\end{array}$ & $\begin{array}{r}-0.2235 \\
(-0.96)\end{array}$ \\
\hline JUNIOR & $\begin{array}{r}0.3271 \\
(4.20)^{* * * *}\end{array}$ & $\begin{array}{r}0.2282 \\
(2.91)^{* * *}\end{array}$ & $\begin{array}{r}0.3786 \\
(1.41)\end{array}$ & $\begin{array}{r}0.2421 \\
(0.74)\end{array}$ \\
\hline SECONDAR & $\begin{array}{r}0.8551 \\
(11.95)^{* * *}\end{array}$ & $\begin{array}{c}0.6937 \\
(9.18)^{* * *}\end{array}$ & $\begin{array}{r}1.0021 \\
(4.92)^{* * *}\end{array}$ & $\begin{array}{r}0.6661 \\
(2.95)^{* * *}\end{array}$ \\
\hline BACHELOR & $\begin{array}{r}1.3949 \\
(18.10)^{* * *}\end{array}$ & $\begin{array}{r}1.1408 \\
(13.07)^{* * *}\end{array}$ & $\begin{array}{r}1.2682 \\
(7.06)^{* * * *}\end{array}$ & $\begin{array}{r}0.5838 \\
(2.08) * *\end{array}$ \\
\hline MASTERS & $\begin{array}{r}1.7544 \\
(17.38)^{* * * *}\end{array}$ & $\begin{array}{r}1.4930 \\
(13.72)^{* * *}\end{array}$ & $\begin{array}{r}1.6435 \\
(9.10)^{* * * *}\end{array}$ & $\begin{array}{r}0.8591 \\
(2.80)^{* * *}\end{array}$ \\
\hline PROF & $\begin{array}{r}1.7823 \\
(18.19)^{* * *}\end{array}$ & $\begin{array}{r}1.4883 \\
(13.70)^{* * *}\end{array}$ & $\begin{array}{r}1.7122 \\
(4.42)^{* * *}\end{array}$ & $\begin{array}{l}0.7964 \\
(1.67)^{*}\end{array}$ \\
\hline PAEDYRS & & $\begin{array}{r}0.0256 \\
(5.87)^{* * * *}\end{array}$ & & $\begin{array}{r}0.0620 \\
(3.13))^{* * * *}\end{array}$ \\
\hline$\angle A M B D A$ & $\begin{array}{r}0.0094 \\
(0.07) \\
\end{array}$ & $\begin{array}{r}-0.0810 \\
(-0.64) \\
\end{array}$ & $\begin{array}{r}0.0137 \\
(0.08) \\
\end{array}$ & $\begin{array}{r}-0.1704 \\
(-1.01) \\
\end{array}$ \\
\hline $\begin{array}{l}\text { Adjusted R-Square } \\
\mathrm{N} \\
\text { Dep. variable mean }\end{array}$ & $\begin{array}{r}0.5773 \\
1009 \\
2.3163 \\
\end{array}$ & $\begin{array}{r}0.5910 \\
1009 \\
2.3163 \\
\end{array}$ & $\begin{array}{r}0.4333 \\
182 \\
1.7390 \\
\end{array}$ & $\begin{array}{r}0.4608 \\
182 \\
1.7390 \\
\end{array}$ \\
\hline
\end{tabular}

Table 8 Estimated marginal rates of return to education

\begin{tabular}{lcccc}
\hline Education cycle & \multicolumn{2}{c}{$\begin{array}{c}\text { Mincerian equation } \\
\text { (From equation 1, table 7) }\end{array}$} & $\begin{array}{c}\text { Mincerian equation with PAEDYRS } \\
\text { (From equation 2, table 7) }\end{array}$ \\
\hline & Women & Men & Women & Men \\
Primary & $-3.2^{*}$ & $2.6^{*}$ & $-4.5^{*}$ & $1.4^{*}$ \\
Junior & $13.4^{*}$ & 4.9 & $11.6 *$ & 4.0 \\
Secondary & 20.8 & 17.6 & 14.1 & 15.5 \\
Bachelors degree & 8.9 & 18.0 & -2.7 & 14.9 \\
Masters degree & 18.8 & 18.0 & 13.8 & 17.6 \\
Professional degree & 14.2 & 18.5 & 2.6 & 15.9 \\
\hline
\end{tabular}

Note: * These rates are not significantly different from zero. 
Table 6 suggested that in our data, women's return to each extra year of schooling was lower than men's retum. Yet, a review of world-wide evidence suggests that, in general, women's schooling is economically at least as profitable as men's (Schultz 1993). Table 8 suggests that in our data, the rate of return to education generally rises with education level. Our negative, zero, or small returns to primary and junior education and comparatively greater returns to secondary and higher education for both men and women are at odds with the conventional world-wide pattern of returns to education perceived by Psacharopoulos (1994) who suggests that returns are generally the greatest for primary level of education and get progressively smaller with each successively higher level of education. It is useful, therefore, to examine the pattern of returns to different levels of education in other Indian studies.

Tables $9 \mathrm{a}$ and $9 \mathrm{~b}$ provide a comparison between the estimated rates of retum to schooling in the present work and the rates estimated by other researchers in India. Table 9a suggests that our finding of poorer returns to women's education than men's is not maverick: it is corroborated by the only other existing studies that provide comparable returns estimates for males and females in India that the author is aware of. Under a pure Mincerian earnings function, women's return to education is about $10 \%$ to $30 \%$ lower than men's return to education in different parts of India. Table $9 \mathrm{~b}$ suggests that our finding that returns to education generally increase with education level is also confirmed by the other studies from different parts of India, suggesting that the conventional pattern of returns to education (greatest for primary and smallest for higher education) does not hold in India. Indeed, the return to each year of primary education in these studies is either negative or, where positive, is typically lower than $3 \%$ and/or is statistically not different from zero ${ }^{23}$.

\footnotetext{
${ }^{23}$ We have not presented evidence from Tilak (1990) or Tilak (1987) in table $9 \mathrm{~b}$ because a comparison is not possible: Tilak's (1990) Mincerian specification of the earnings function does not include education level dummies but simply 'years of education'. The rate of return estimates in Tilak (1987) are not comparable because they are calculated using the cost-benefit method, that is, they take the costs of schooling into account as well. It is worth mentioning, though, that Tilak's $(1987, \mathrm{p} 99)$ fully adjusted returns estimates show negative returns to women's
} 
Table 9a: Marginal rate of return to education in India: Estimates from various studies

\begin{tabular}{llllc}
\hline \multicolumn{1}{c}{ Author } & Year & \multicolumn{1}{c}{ Region } & \multicolumn{2}{c}{ Rate of return } \\
& & & Men & Women \\
\hline Kingdon $^{*}$ & $1996^{*}$ & Urban Uttar Pradesh & $8.9^{b}$ & $4.9^{b}$ \\
& & & & \\
Kingdon & $1996^{*}$ & Utban Uttar Pradesh & 10.6 & 9.6 \\
Malathy & 1989 & Urban Tamil Nadu & 16.4 & 14.9 \\
Tilak & 1990 & Rural \& Urban Andhra Pradesh & $5.3^{b}$ & $3.6^{b}$ \\
Duraisamy & 1988 & Rural Tamil Nadu & $3.2^{b}$ & $0.8^{b}$ \\
\hline
\end{tabular}

Notes: * Present study. "Specification with parental background. All other estimates are based on a pure Mincerian specification. 'The male and female estimated returns to schooling are statistically different at the $5 \%$ level.

Unfortunately the only study using the Indian National Sample Survey data (Unni 1995) does not report a specification with 'years of schooling' as a variable.

Table 9b: Mincerian returns to education, by level: Estimates from various studies

\begin{tabular}{|c|c|c|c|c|c|c|c|}
\hline & \multicolumn{2}{|c|}{ Kingdon $^{2}$} & \multicolumn{2}{|c|}{ Unni $(T N)^{b}$} & \multicolumn{2}{|c|}{ Unni $(\mathrm{MP})^{\mathrm{c}}$} & \multirow{2}{*}{$\begin{array}{c}\text { B \& K } \\
\text { Men }\end{array}$} \\
\hline & Men & Women & Men & Women & Men & Women & \\
\hline Primary & $2.6^{*}$ & $-3.2^{*}$ & 2.9 & $0.0 *$ & 3.1 & $6.0^{*}$ & 2.4 \\
\hline Junior & 4.9 & $13.4^{*}$ & 9.0 & 11.5 & 9.7 & $-18.2 *$ & - \\
\hline Secondary & 17.6 & 20.8 & 17.0 & 20.0 & 12.0 & 64.9 & 6.9 \\
\hline Higher & $18.2^{+}$ & $14.0^{+}$ & 15.6 & 27.0 & 13.5 & 11.0 & 11.4 \\
\hline
\end{tabular}

Notes: * These rates are not statistically different from zero. " Present study on urban Utar Pradesh; ${ }^{b}$ Unni (1995) on urban Tamil Nadu; ' Unni (1995) on urban Madhya Pradesh; ' Banerjee and Knight (1985) on urban Delhi. ${ }^{+}$Taken as the average of all returns to post-primary levels of education in table 8.

The pattern of low returns to primary education in India seen in table $9 b$ is consistent with the suggestion that over time the rate of return to primary education may have collapsed in many countries. For example, Moll (1996) reports that the Mincerian rate of return to African primary

primary education, and the percentage returns to each year of education in junior, secondary, and higher education are $1.2 \%, 3.3 \%$ and $3.2 \%$ respectively. In other words, the return to primary education is negative and returns rise with education level. It also shows that men's returns to education are roughly constant at about $6 \%$ for all levels of education. 
education in South Africa has been $2-4 \%$ since the early 1970 s. In Cote'd-Ivoire and Uganda the rates are 5 and 4\% respectively (Appleton, Hoddinott, and Knight 1996), and in Ethiopia the rate is estimated at 1\% (Appleton, Hoddinott, Krishnan and Max 1995). In urban areas of Sri Lanka, there are zero wage returns to primary and secondary education, and the rates of return increase with education level (Sahn and Alderman 1988). These findings call into question the long-held view that rates of retum to primary education are high (typically much greater than 10\%) and greater than those in higher levels of education. Indeed, the rate of return calculations reported in Psacharopoulos (1994) and which form the basis for the conventional wisdom that returns to primary education are the highest, are now thought to be out-of-date as well as methodologically suspect (see Bennell 1995,1996 for a wide ranging critique).

\section{The extended earnings function}

While a Mincerian eamings function is required for estimating rates of return to education, it is necessarily a narrow and focussed exercise. Earnings are explained not only by variations in human capital but also by compensating differentials, household composition, and institutional factors such as job characteristics, labour market segmentation, unionisation, and ownership (public or private). Indeed, some of the influence of education on eamings works through variables such as occupation, ownership, and union status, etc. For example, education is usually an important determinant of occupational attainment, union status, and of access to lucrative government sector jobs. Our dataset is unusual for developing countries in that it contains information on institutional factors and therefore allows an investigation of the relative importance of such factors. Table 10 presents an extended earnings function for each gender, with and without the family background variable PAEDYRS. 
We are interested in discovering whether there is any sex-discrimination in the labour market, that is, whether wornen with equivalent characteristics as men earn less than their male counterparts. It would also be useful to be able to pin-point the sources of the discrimination. The results of the eamings function in table 10 are used to decompose the gross gender difference in eamings into the part that is explained by men and women's different average characteristics and the part that is due to their differing earnings structures or discrimination.

The proportion of the variation in the dependent variable that is explained (R-Square) goes up substantially, particularly for females, when the Mincerian eamings function is extended. Notice that while on a priori bases, we expected selectivity effects to exist for women they are, in fact, important only to men in our data. This may be because the choice is as between paid employment on the one hand and unemployment and unpaid family employment on the other. The positive and significant coefficient on lambda in the men's equation can be interpreted as follows: men who, according to the participation equation of the previous section, are unlikely to be in paid employment but who are nevertheless observed to be in paid-employment (ie the non-participanttypes) earn more than others. They may have some unobserved motivation, ability, or drive that makes them more likely to be higher earners.

While MARRIED men earn significantly more than unmarried men, the effect is smaller and insignificant for women. However, being married may be somewhat endogenous to earnings: those who earn more may be more likely to get married.

Low and backward caste persons (LOWCASTE) have very significantly lower earnings than high caste persons among both the sexes, but the effect is quantitatively much larger for women. However, when family background is controlled, the coefficient on the caste dummy becomes 
Table 10 Extended earnings functions

\begin{tabular}{|c|c|c|c|c|}
\hline \multirow[t]{2}{*}{ Variable } & \multicolumn{2}{|c|}{ Men } & \multicolumn{2}{|c|}{ Women } \\
\hline & Equation 1 & Equation 2 & Equation 1 & Equation 2 \\
\hline Intercept & $\begin{array}{l}0.4251 \\
(3.21)^{* * *}\end{array}$ & $\begin{array}{l}0.3741 \\
(2.86)^{* * *}\end{array}$ & $\begin{array}{l}0.5868 \\
(2.21)^{* *}\end{array}$ & $\begin{array}{l}0.6139 \\
(2.34) * * *\end{array}$ \\
\hline EXPER & $\begin{array}{l}0.0483 \\
(6.38)^{* * *}\end{array}$ & $\begin{array}{l}0.0518 \\
(6.92)^{* * *}\end{array}$ & $\begin{array}{l}0.0399 \\
(2.38)^{* * *}\end{array}$ & $\begin{array}{l}0.0396 \\
(2.39)^{* * *}\end{array}$ \\
\hline EXPERSQ & $\begin{array}{l}-0.0008 \\
(-4.50) * * *\end{array}$ & $\begin{array}{l}-0.0009 \\
(-4.82) * * *\end{array}$ & $\begin{array}{l}-0.0011 \\
(-2.13) * *\end{array}$ & $\begin{array}{l}-0.0010 \\
(-2.01)^{* *}\end{array}$ \\
\hline LOWCASTE & $\begin{array}{l}-0.1030 \\
(-2.36)^{* * *}\end{array}$ & $\begin{array}{r}-0.0519 \\
(+1.18)\end{array}$ & $\begin{array}{l}-0.2791 \\
(-2.35) * * *\end{array}$ & $\begin{array}{l}-0.2365 \\
(-2.00) * *\end{array}$ \\
\hline MUSLJM & $\begin{array}{r}-0.0382 \\
(-0.68)\end{array}$ & $\begin{array}{r}-0.0012 \\
(-0.02)\end{array}$ & $\begin{array}{r}-0.1664 \\
(-1.10)\end{array}$ & $\begin{array}{r}-0.1467 \\
(-0.98)\end{array}$ \\
\hline WCOLLAR & $\begin{array}{l}0.1824 \\
(3.44) * * *\end{array}$ & $\begin{array}{l}0.1500 \\
(2.85) * * *\end{array}$ & $\begin{array}{r}-0.2924 \\
(-1.35)\end{array}$ & $\begin{array}{r}-0.2947 \\
(-1.38)\end{array}$ \\
\hline UNION & $\begin{array}{l}0.1107 \\
(1.81)^{*}\end{array}$ & $\begin{array}{r}0.0966 \\
(1.60)\end{array}$ & $\begin{array}{c}0.3331 \\
(1.89)^{*}\end{array}$ & $\begin{array}{l}0.3023 \\
(1.735)^{*}\end{array}$ \\
\hline GOVT & $\begin{array}{l}0.3238 \\
(4.98) * * *\end{array}$ & $\begin{array}{l}0.3443 \\
(5.36)^{* * *}\end{array}$ & $\begin{array}{l}0.7064 \\
(3.93) * * *\end{array}$ & $\begin{array}{l}0.6942 \\
(3.92) * * *\end{array}$ \\
\hline SIZE & $\begin{array}{r}0.0002 \\
(0.84)\end{array}$ & $\begin{array}{r}0.0002 \\
(1.03)\end{array}$ & $\begin{array}{r}0.0012 \\
(1.59)\end{array}$ & $\begin{array}{r}0.0012 \\
(1.56)\end{array}$ \\
\hline WORKHOME & $\begin{array}{r}0.1129 \\
(0.95)\end{array}$ & $\begin{array}{r}0.0815 \\
(0.69)\end{array}$ & $\begin{array}{l}-0.5791 \\
(-4.15)^{* * *}\end{array}$ & $\begin{array}{l}-0.5770 \\
(-4.19) * * *\end{array}$ \\
\hline MARRIED & $\begin{array}{l}0.2835 \\
(3.78) * * *\end{array}$ & $\begin{array}{l}0.2760 \\
(3.73) * * *\end{array}$ & $\begin{array}{r}0.1404 \\
(1.10)\end{array}$ & $\begin{array}{r}0.1383 \\
(1.10)\end{array}$ \\
\hline TRAINING & $\begin{array}{l}0.1226 \\
(2.11) * *\end{array}$ & $\begin{array}{l}0.0962 \\
(1.67) *\end{array}$ & $\begin{array}{c}0.2200 \\
(1.66)\end{array}$ & $\begin{array}{l}0.2305 \\
(1.76)^{*}\end{array}$ \\
\hline EDYRS & $\begin{array}{l}0.0786 \\
(15.52)^{* * *}\end{array}$ & $\begin{array}{l}0.0674 \\
(12.46)^{* * *}\end{array}$ & $\begin{array}{l}0.0643 \\
(4.30)^{* * *}\end{array}$ & $\begin{array}{l}0.0419 \\
(2.40) * * *\end{array}$ \\
\hline PAEDYRS & & $\begin{array}{l}0.0231 \\
(5.35)^{* * *}\end{array}$ & & $\begin{array}{l}0.0339 \\
(2.40) * * *\end{array}$ \\
\hline$\angle A M B D A$ & $\begin{array}{l}0.3396 \\
(2.35)^{* * *}\end{array}$ & $\begin{array}{c}0.2536 \\
(1.77)^{*}\end{array}$ & $\begin{array}{r}0.1747 \\
(1.33)\end{array}$ & $\begin{array}{r}0.1180 \\
(0.89)\end{array}$ \\
\hline $\begin{array}{l}\text { Adjusted } \\
\text { R-Square }\end{array}$ & 0.6243 & 0.6345 & 0.6864 & 0.6950 \\
\hline $\begin{array}{l}\mathrm{N} \\
\text { Dependent } \\
\text { variable mean }\end{array}$ & $\begin{array}{c}1008 \\
2.3156\end{array}$ & $\begin{array}{c}1008 \\
2.3156\end{array}$ & $\begin{array}{c}181 \\
1.7486\end{array}$ & $\begin{array}{c}181 \\
1.7486\end{array}$ \\
\hline
\end{tabular}

Note: T-statistics are in parentheses. * represents significance at the $10 \%$ level, ** at the $5 \%$ level, and *** at the $1 \%$ level. 
insignificant in the men's earnings function, suggesting that lowcaste men do not face significant direct wage discrimination in the labour market: their earnings disadvantage obtains importantly from their more deprived backgrounds which may influence earnings indirectly via lower out-ofschool investments in learning and lower quality education, or indeed, via less influential connections in the job market.

Among women, controlling for family background marginally reduces the apparent earnings disadvantage of lowcaste women but does not render it insignificant, indicating that low and backward caste women do face direct wage/earnings discrimination in the labour market. This finding suggests that while the lowcaste boys' demand for education will not be significantly different to that of high caste boys after controlling for other factors, lowcaste girls will acquire significantly less education than high caste girls because they face lower economic incentives in the labour market. This inference is supported by the educational attainment analysis in Kingdon (1995) where the LOWCASTE dummy is insignificant in the male educational attainment regression but significant in the female regression.

While men in white collar occupations (WCOLLAR) earn significantly more than those in other occupations, this result does not hold true for women in white collar occupations. This at least partly reflects the occupational distribution of men and women within the broad category 'white collar'. For example, while $37 \%$ of all men in white collar occupations were in the managerial and professional occupations, only $3 \%$ of white collar women were working as managers or professionals. A good proportion of white collar women were in low paid teaching jobs in the private sector or gave private tuitions at home as a casual earning activity. 
Both unionised men and women (UNION) earn significantly more than their non-unionised counterparts though the magnitude of the union effect is much greater for women. The same is true of workers in the government sector. The large coefficient on GOVT in men's and particularly women's eamings functions highlights that the labour market is likely to be segmented by sector ${ }^{24}$. It is not surprising then that in India, government jobs are by far the most sought-after.

For women, working at home (WORKHOME) is associated with significantly lower earnings compared to those who work outside home. Few men work at home and so in the men's earnings function there is little information to distinguish the effect, on earnings, of working at home and outside work. The effect for women may be explained by a compensating differentials or equalising differences type of reasoning: those women who, because of custom or disinclination, prefer working at home are remunerated substantially less than those who incur the inconvenience, time-cost, and travel-cost of working out of the home.

\section{Conclusion}

The results reveal that there is a substantial bias in the estimates of the rates of return to education in India if family background is ignored. Controlling for background, women endure much lower returns to education than men, suggesting that they face much poorer economic incentives to invest in education than males. The results also suggest that, contrary to the conventional pattern, returns to the first 5 years of education are very low in urban India both for men and women, and retums generally rise with education level. This finding is corroborated by the results in other Indian studies. Institutional factors are important in explaining a large amount of the variation in earnings and there is indication that the urban labour market is segmented along public-private lines.

\footnotetext{
${ }^{24}$ This suggests that the analysis of earnings should be carried out disaggregated by sector. However, with a small sample of working women, this is beyond the scope of the present study.
} 


\section{Discrimination in the labour market}

We wish to test whether women with comparable characteristics to men earn similar incomes. We also want to examine the contribution of individual variables to the male-female gap in earnings. To achieve this, we decompose the gross difference in mean earnings between men and women into the component 'explained' by differences in characteristics between the two groups, and the 'unexplained' component which is regarded in the literature as the extent of sex discrimination in the labour market (Berndt 1991, Cain 1986). We use the Blinder-Oaxaca technique (Oaxaca 1973) for measuring discrimination when two groups of people differ in their characteristics and differ in the eamings structure relating these characteristics to earnings.

Assume that the mean earnings of females $(f)$ are $\bar{Y}_{f}$ and those of males $(m)$ are $\bar{Y}_{m}$. Mean earnings are determined by

$$
\bar{Y}_{i}=\hat{b}_{i} \bar{X}_{i} \quad i=f, m
$$

where $\bar{X}$ is the vector of the mean values of characteristics and $\hat{b}$ is the vector of estimated coefficients of the earnings function.

The mean earnings of men, if they earned according to the women's earnings function would be the dot product $\hat{b}_{f} \bar{X}_{m}$. The total gender difference $(T)$ in mean earnings can be divided into the part explained (E) by the different personal characteristics of men and women and the part unexplained (D), reflecting differences in the earnings structure, that is, differences in $\hat{b}$ for the two sexes. 


$$
\begin{aligned}
& T=\bar{Y}_{m}-\bar{Y}_{f} \\
& T=\hat{b}_{m} \bar{X}_{m}-\hat{b}_{f} \bar{X}_{f} \\
& T=\left\{\bar{X}_{m}\left(\hat{b}_{m}-\hat{b}_{f}\right)\right\}+\left\{\hat{b}_{f}\left(\bar{X}_{m}-\bar{X}_{f}\right)\right\} \\
& T=D+E
\end{aligned}
$$

This can be referred to as standardising by male means. Similarly, the estimation of the earnings of women if they are paid according to the men's earnings function permits the decomposition into $\mathrm{D}+\mathrm{E}$ as follows:

$$
\begin{aligned}
& T=\bar{Y}_{m}-\bar{Y}_{f} \\
& T=\hat{b}_{m} \bar{X}_{m}-\hat{b}_{f} \bar{X}_{f} \\
& T=\left\{\bar{X}_{f}\left(\hat{b}_{m}-\hat{b}_{f}\right)\right\}+\left\{\hat{b}_{m}\left(\bar{X}_{m}-\bar{X}_{f}\right)\right\} \\
& T=D+E
\end{aligned}
$$

This can be referred to as standardising by female means. Since the decomposition may be sensitive to the choice of index (standardising according to male means or female means), ideally both decompositions should be carried out.

Following the procedure just outlined, we decompose the observed earnings difference between men and women into two components, that due to gender differences in characteristics (E) and that due to gender differences in the eamings structure or coefficients (D). We do this for each variable to examine the contribution of each individual variable to the gender difference in earnings. The results are presented in table 11 . 
When expressed in terms of natural logs, the gross earnings difference between men and women is $32 \%$. Observe the totals row (i.e. the last row) first: Standardising according to male means, only 0.242 out of 0.563 (or $43 \%$ ) of the observed gender difference in earnings is due to men's superior earnings characteristics; $57 \%$ of this gross difference in earnings is unexplained, suggesting a high level of discrimination. Standardising by female means, all of the gender gap (102\%) in earnings is unexplained by differing characteristics. If we follow Greenhalgh (1980) is regarding the average of the two as the best measure of discrimination, then, in table 12 (which presents the average of the two standardisations) only $20 \%$ of the gross earnings difference between males and females is due to gender differences in characteristics and $80 \%$ appears to be discriminatory, that is, explained by differing earnings structures for men and women.

Consider the contribution of individual variables to the male-female gap in earnings in table 12. The most important reason why men have higher hourly earnings than women is that they have more human capital (more education and experience) than women and, more importantly, because their eamings respond more to human capital variables than do women's eamings. That is, men's returns to education and to experience are greater than women's returns to these assets.

For example, education alone accounts for $58 \%$ of the gross gender gap in eamings in table 12 (education contributes 0.327 to the total gender gap of 0.563 ). Of the total effect of education on earnings (0.327), only 0.072 or $22 \%$ is due to men's higher levels of education than women but a much larger 0.255 or $78 \%$ is due to men's higher returns to education. Similarly, experience explains about $50 \%$ of the total gender difference in earnings. Of the portion of the gap explained by experience, on average, only $32 \%$ is due to men's longer years of experience, while men's higher returns to experience are responsible for a large $68 \%$ of the gender gap in earnings due to experience. 
Table 11 Decomposition of the gender difference in log of hourly earnings (standardising by both male and female mean characteristics)

\begin{tabular}{|c|c|c|c|c|c|c|}
\hline \multirow[t]{2}{*}{ Variable } & \multicolumn{3}{|c|}{ Standardising by female means } & \multicolumn{3}{|c|}{ Standardising by male means } \\
\hline & characteristics & coefficients & $\begin{array}{c}\text { combined } \\
\text { effect }\end{array}$ & characteristics & coefficients & $\begin{array}{l}\text { combined } \\
\text { effect }\end{array}$ \\
\hline Intercept & 0.000 & -0.240 & -0.240 & 0.000 & -0.240 & -0.240 \\
\hline \multicolumn{7}{|c|}{ Human capital variables } \\
\hline EDYRS & 0.089 & 0.238 & 0.327 & 0.055 & 0.271 & 0.327 \\
\hline TRAINING & -0.015 & -0.038 & -0.053 & -0.035 & -0.017 & -0.053 \\
\hline EXPER & 0.282 & 0.129 & 0.411 & 0.215 & 0.195 & 0.411 \\
\hline EXPERSQ & -0.152 & 0.020 & -0.132 & -0.170 & 0.038 & -0.132 \\
\hline$A L L$ & 0.204 & 0.349 & 0.553 & 0.065 & 0.488 & 0.553 \\
\hline \multicolumn{7}{|c|}{ Personal and parental variables } \\
\hline LOWCAST & 0.003 & 0.069 & 0.072 & 0.012 & 0.060 & 0.072 \\
\hline MUSLIM & 0.000 & 0.021 & 0.021 & 0.000 & 0.021 & 0.021 \\
\hline MARRIED & 0.009 & 0.103 & 0.113 & 0.005 & 0.108 & 0.113 \\
\hline PAEDYRS & -0.006 & -0.076 & -0.082 & -0.009 & -0.073 & -0.082 \\
\hline$\angle A M B D A$ & -0.247 & 0.178 & -0.070 & -0.115 & 0.045 & -0.070 \\
\hline$A L L$ & -0.241 & 0.295 & 0.054 & -0.107 & 0.161 & 0.054 \\
\hline \multicolumn{7}{|c|}{ Occupation and work-related variables } \\
\hline WCOLLAR & -0.014 & 0.236 & 0.222 & 0.027 & 0.195 & 0.222 \\
\hline UNION & 0.012 & -0.052 & -0.040 & 0.038 & -0.078 & -0.040 \\
\hline GOVT & 0.030 & -0.114 & -0.084 & 0.060 & -0.144 & -0.084 \\
\hline SIZE & 0.010 & -0.036 & -0.025 & 0.052 & -0.077 & -0.025 \\
\hline WORKHOME & -0.015 & 0.138 & 0.123 & 0.107 & 0.016 & 0.123 \\
\hline$A L L$ & 0.023 & 0.172 & 0.196 & 0.284 & -0.088 & 0.196 \\
\hline Total & -0.014 & 0.577 & 0.563 & 0.242 & 0.321 & 0.563 \\
\hline $\begin{array}{l}\text { \% of difference } \\
\text { explained by } \\
\text { coefficients }\end{array}$ & & $102.5 \%$ & & & $57.0 \%$ & \\
\hline
\end{tabular}


It should be stated that the estimate of discrimination may be somewhat exaggerated here. This is because while we have measured years of work experience, the measure does not capture the intensity of work experience. As stated in section V, men may have longer average hours of work per year than women and, thus, greater learning-by-doing'. However, even allowing for these considerations, there still appears to be a substantial element of sex discrimination in the returns to the human capital variables. For example, although we have controlled for quality of education via the background variable, returns to education are still considerably lower for females than males.

Other variables that are important in explaining the gender gap in earnings are occupation and marriage status. Men in white collar occupations earn significantly more than others while this is not true for women (possible reasons discussed earlier). Not only are more men in the sample married, but men have higher returns to marriage, ceteris paribus, and the two effects reinforce each other. In summary, the male-female earnings gap is explained only to a small extent by women's inferior characteristics (such as lower education, experience, and white collar occupational attainment) but to a larger extent by the differential way in which the Iabour market appears to reward these characteristics for the two genders. 
Table 12 Decomposition of the gender difference in hourly earnings (Average of the two gender standardisations in table 11)

\begin{tabular}{|c|c|c|c|c|c|}
\hline \multirow[t]{2}{*}{ Variable } & \multicolumn{2}{|c|}{ Means of characteristics } & \multicolumn{2}{|c|}{ Difference in earnings due to } & \multirow[b]{2}{*}{ combined effect } \\
\hline & Men & Women & characteristics & coefricients & \\
\hline Intercept & - & - & 0.000 & -0.240 & +0.240 \\
\hline \multicolumn{6}{|c|}{ Human capital variables } \\
\hline EDYRS & 10.659 & $9.309 * * *$ & 0.072 & 0.255 & 0.327 \\
\hline TRAINING & 0.131 & $0.282 * * *$ & -0.025 & -0.028 & -0.053 \\
\hline EXPER & 16.027 & $10.558 * * *$ & 0.249 & 0.162 & 0.411 \\
\hline EXPERSQ & 374.090 & $199.88 * * *$ & -0.161 & 0.029 & -0.132 \\
\hline$A L L$ & & & 0.134 & 0.419 & 0.553 \\
\hline \multicolumn{6}{|c|}{ Personal and parental variables } \\
\hline LOWCAST & 0.324 & 0.376 & 0.008 & 0.064 & 0.072 \\
\hline MUSLM & 0.143 & 0.144 & 0.000 & 0.021 & 0.021 \\
\hline MARRIED & 0.788 & 0.751 & 0.007 & 0.106 & 0.113 \\
\hline PAEDYRS & 6.763 & 7.022 & -0.008 & -0.074 & -0.082 \\
\hline$\angle A M B D A$ & 0.335 & $1.311^{* * *}$ & -0.181 & 0.111 & -0.070 \\
\hline$A L L$ & & & -0.174 & 0.228 & 0.054 \\
\hline \multicolumn{6}{|c|}{ Occupation and work-related variables } \\
\hline WCOLLAR & 0.440 & $0.530^{* *}$ & 0.007 & 0.215 & 0.222 \\
\hline UNION & 0.380 & $0.254 * * *$ & 0.025 & -0.065 & -0.040 \\
\hline$G O V T$ & 0.412 & $0.326 * * *$ & 0.045 & -0.129 & -0.084 \\
\hline SIZE & 80.313 & $37.37 * * *$ & 0.031 & -0.056 & -0.025 \\
\hline WORKHOME & 0.025 & $0.210 * * *$ & 0.046 & 0.077 & 0.123 \\
\hline$A L L$ & & & 0.154 & 0.042 & 0.196 \\
\hline Total & & & 0.114 & 0.449 & 0.563 \\
\hline
\end{tabular}

Note: Where the difference in the mean characteristics of males and females is statistically different from zero, this is indicated by asterisks. ***, and *** represent significance at the $10 \%, 5 \%$ and $1 \%$ levels respectively: 


\section{Conclusions and policy implications}

Controlling for family background, women have significantly lower returns to education than men, suggesting that they face inferior economic incentives to invest in education than males. This substantial gender asymmetry in the pay-offs of education is likely to be an important part of any explanation for Indian women's observed lower average educational attainment than men's.

The analysis suggests that policies to encourage women's education will enhance their labour force participation - given our evidence of a positive relation between education above junior level and work participation. Policies to remove sex-discrimination in the labour market will raise the rates of return to women's education and enhance women's incentives to invest in education. In other words, the two policy measures would be mutually re-inforcing.

Our finding of low or insignificant returns to both and women's and men's education at the primary and junior (elementary) education levels should not be used to suggest that it is no longer necessary for education policy to emphasise elementary education in India, or in urban India. For one thing, our rate calculations refer only to the private returns of education. The social returns of elementary education may be substantial. Moreover, elementary education is a necessary input into education at the secondary level and above; the indirect benefit of elementary education is its role in helping access to post-elementary education. A recent attempt to quantify this indirect benefit in Cote divoire and Uganda showed that the value of acquiring this 'option' to continue on to secondary education can be quantitatively important even if the direct private returns to elementary education are very low (see Appleton, Hoddinott, and Knight 1996). 
Similarly, the finding of lower rates of return to women's education than men's should not be used to argue that in India, there is a weaker efficiency case for promoting girls' education than boys'. This is because our estimates measure only the private returns to education. Female education has a host of social benefits such as reduced infant mortality and lower fertility which are thought to be very substantial ${ }^{25}$. 
Pooled binary probit model of paid work force participation, with gender interactions

\begin{tabular}{|c|c|c|c|}
\hline Variable & Coefficient & t.ratio & Marginal effect \\
\hline Intercept & -0.3203 & -0.69 & -0.127 \\
\hline$A G E$ & 0.0604 & $2.10 * *$ & 0.024 \\
\hline$A G E S Q$ & -0.0011 & $-2.85^{* * *}$ & -0.000 \\
\hline$M A W O R K E D$ & 0.0930 & 1.29 & 0.037 \\
\hline PAEDYRS & 0.0073 & 0.74 & 0.003 \\
\hline PAWEAL & -0.0305 & $-4.49 * * *$ & -0.012 \\
\hline MARRIED & 0.4242 & $3.03^{* * *}$ & 0.168 \\
\hline$H E A D$ & 0.5819 & $4.79 * * *$ & 0.230 \\
\hline NCHILDI4 & -0.2726 & -0.71 & -0.011 \\
\hline DCENTRE & -0.1591 & $-1.90^{*}$ & -0.006 \\
\hline$H E A L 7$ & -0.1946 & $-1.71^{*}$ & -0.077 \\
\hline LOWCASTE & 0.0399 & 0.43 & 0.016 \\
\hline EDYRS & 0.0362 & $3.58^{* * *}$ & 0.014 \\
\hline TRAINING & 0.3496 & $2.35^{* *}$ & 0.138 \\
\hline FEMALE & -2.1541 & $-2.97^{* * *}$ & -0.852 \\
\hline$F A G E$ & 0.0306 & 0.69 & 0.012 \\
\hline$F A G E S Q$ & -0.0000 & -0.10 & -0.000 \\
\hline FMAWORK & 0.2615 & $2.53^{* *}$ & 0.104 \\
\hline FPAEDYRS & -0.0330 & $-2.09^{* *}$ & -0.013 \\
\hline FPAWEAL & 0.0213 & $1.88^{*}$ & 0.008 \\
\hline FMARRIED & -1.0664 & $-4.81 * * *$ & -0.422 \\
\hline$F H E A D$ & 0.4030 & $1.86^{*}$ & 0.159 \\
\hline FNCHILD 14 & -0.0144 & -0.25 & -0.006 \\
\hline FDCENTRE & 0.0224 & $1.76^{*}$ & 0.009 \\
\hline FHEAL7 & 0.0436 & 0.27 & 0.017 \\
\hline FLOWCAST & 0.2553 & $1.78^{*}$ & 0.101 \\
\hline FEDYRS & 0.0050 & 0.31 & 0.002 \\
\hline FTRAINING & 0.1619 & 0.84 & 0.064 \\
\hline $\log L$ & & -1127.112 & \\
\hline Restricted $\log L$ & & -1848.952 & \\
\hline Psuedo $R^{2}$ & & 0.3904 & \\
\hline $\mathrm{N}$ & & 2675 & \\
\hline
\end{tabular}




\section{References}

Appleton, S, P Collier and P Horsnell (1990) "Gender, education, and employment in Cote d'Ivoire" Social dimensions of adjustment in Sub-Saharan Africa Working Paper No. 8, World Bank, Washington D.C.

Appleton, S, J Hoddinott, and J Knight (1996) "Primary education as an input into post-primary education: A neglected benefit", Oxford Bulletin of Economics and Statistics, 58 (1).

Appleton, S, J Hoddinott, P Krishnan, and K Max (1995) "Does the labour market explain low female schooling? Evidence from three African countries", Discussion Paper No. 152, Centre for the Study of African Economies, Oxford University.

Banerjee, B and J B Knight (1985) "Caste discrimination in the Indian labour market", Joumal of Development Economics 17, 277-307.

Bardhan, P (1987) "On the economic geography of sex disparity in child survival in India: A note", Mimeo, Paper presented at BAMANEH/Ameican SSRC Workshop on Differential Female Mortality and Health Care in South Asia, Dhaka.

Behrman, J and Nancy Birdsall (1983) "Quality of schooling: Quantity alone is misleading”, American Economic Review 73, No. 5 (December): 928-946.

Behrman $\mathbf{J}$ and B Wolfe (1984), "The socio-economic impact of schooling in a developing country", Review of Economics and Statistics 66 (2), 296-303.

Bennell, Paul (1995) "Rates of return to education in Asia: A review of the evidence", Institute of Development Studies Working Paper No. 24, Sussex.

Bennell, Paul (1996) "Rates of return to education : Does the conventional pattern prevail in SubSaharan Africa?", World Development, 24 (1), 183-199.

Berndt, E R (1991) The practice of econometrics: classic and contemporary, New York: Addison Wesley.

Cain, G G (1986) "Labour Market Discrimination" in O. Ashenfelter and R. Layard (ed.) Handbook of Labour Economics, Amsterdam: North Holland.

Chen, M and J Drèze (1992) "Widows and well-being in rural north India", Discussion Paper No. 40, Development Economics Research Programme, STICERD, London School of Economics, London.

Datta, R C (1985) "Education and the distribution of eamings" Artha Vijnana 27 (1) March, 1-20.

Drèze, Jean and H Gazdar (1996) "Uttar Pradesh: The Burden of Inertia" in J Drèze and A Sen (eds). Indian Development: Selected Regional Perspectives, Oxford University Press, Delhi.

Drèze, Jean and P V Srinivasan (1996) "Poverty in India: Regional estimates", Discussion Paper No. 70, Development Economics Research Programme, STICERD, London School of Economics. 
Duraisamy, P (1988) "An econometric analysis of fertility, child schooling and labour force participation of women in rural Indian households" Journal of Quantitative Economics 4 (2), 293316.

Glewwe, Paul (1991) "Schooling, skills, and the returns to government investment in education", Living Standards Measurement Study Working Paper No. 76, World Bank: Washington D.C.

Greene, W.H. (1993) Econometric Analysis, 2nd Edition, New York: Macmillan.

Greenhalgh, C (1980) "Male-female wage differentials in Great Britain: Is marriage an equal opportunity?", Economic Journal, 90: 751-75.

Haddad L, J Hoddinott, and H Alderman (1994) "Intrahousehold resource allocation: An introduction", Policy Research Paper, The World Bank, Washington D.C.

Heckman, James (1979) "Sample selection bias as a specification error", Econometrica 47, No. 1: 153-161.

Heckman, J J and V J Hotz (1986), "An investigation of the labour market earnings of Panamanian males: evaluating the sources of inequality", Journal of Human Resources 21, 507-542.

Husain, I Z (1969) "Returns approach to educational planning" in Pandit H N (ed) Measurement of cost productivity and efficiency of education, NCERT, New Delhi.

King, E and M Hill (1993) Women's education in developing countries, John Hopkins Press for the World Bank, Washington D.C.

Kingdon, Geeta Gandhi (1994), "An economic evaluation of school managment-types in urban India: A case study of Uttar Pradesh”, Unpublished D.Phil. thesis, University of Oxford.

Kingdon, Geeta Gandhi (1995), "Education of Females in India: Determinants and Economic Consequences", Draft Report submitted to the McNamara Fellowships Office of the World Bank, Washington D.C., December 1995.

Kingdon, Geeta Gandhi (1996a) "The quality and efficiency of private and public education: A case-study of urban India", Oxford Bulletin of Economics and Statistics, 58 (1), 57-82.

Kingdon, Geeta Gandhi (1996b) "Private Schooling in India: Size, Nature, and Equity-Effects", Discussion Paper No. 72, Development Economics Research Programme, STICERD, London School of Economics, May 1996.

Kingdon, Geeta Gandhi (1996c) "Student Achievement and Teacher Pay: A Case-Study of India", Discussion Paper No. 74, Development Economics Research Programme, STICERD, London School of Economics, August 1996.

Knight, J and R Sabot (1990) Education, Productivity, and Inequality: The East African Natural Experiment, Oxford: Oxford University Press for the World Bank.

Lam D and R F Schoeni (1993) "Effects of family background on eamings and returns to schooling: evidence from Brazil", Journal of Political Economy 101. 
Lockwood, M and P Collier (1988) "Maternal education and the vicious cycle of high fertility and malnutrition: An analytic survey", Policy, Planning and Research Working Paper, WPS 130, World Bank, Washington D.C.

Maddala, G S (1989) Introduction to Econometrics, New York: Macmillan.

Malathy, R (1989) "Labour supply behaviour of married women in urban India", Discussion Paper No. 585, Economic Growth Center, Yale University, October 1989.

Mathur, Ashok (1994) "Work participation, gender, and economic development: A quantitative anatomy of the Indian scenario", Joumal of Development Studies 30, Jan. 1994: 466-504.

Moll, Peter (1996) "The collapse of primary schooling returns in South Africa, 1960-90", Oxford Bulletin of Economics and Statistics, $\mathbf{5 8}$, No. 1, forthcoming.

Murthi, M, A Guio, and J Drèze (1996) "Mortality, fertility, and gender bias in India", in J Drèze and A Sen (eds.) Indian Development: Selected Regional Perspectives, Oxford University Press, Delhi.

Nigam, Nomita (1993) "Women in secretarial jobs: A study of their employment, income, and working conditions in Lucknow city", Unpublished P.Hd. thesis, Kanpur University, Uttar Pradesh.

Nirmala V, K Bhatt, M Mohsin and B Kamaiah (1992), "Work participation behaviour of married women with living husbands: a case of Pondicherry", Artha Vijnana 34, 315-336.

NSSO (1992) "Results of the fourth quinquennial survey on employment and unemployment", Sarvekshna, Special issue, 43rd Round, 1987-88, State Series (Report for Uttar Pradesh).

Oaxaca, R (1973) "Male-female differentials in urban labour markets", Intemational Economic Review, 3, Oct., 603-709.

Panchmukhi V R and P Panchmukhi (1969) "Socio-economic variables and urban incomes" in Pandit, $\mathbf{H}$ (ed) Measurement of Cost Productivity and efficiency of education, NCERT, New Delhi.

Psacharopoulos, G (1994) "Retums to investment in education: A global update", World Development, 22 (9), 1325-44.

Rosenzweig, M and T P Schultz (1982) "Market opportunities, genetic endowments, and intrafamily resource distribution: Child survival in rural India", American Economic Review, Sept: 803-815.

Sahn, D and H Alderman (1988), "The effects of human capital on wages and the determinants of labour supply in a developing country", Journal of Development Economics 29, 157-183.

Schultz, T P (1993) "Returns to women's education" chapter 2 in King, E and M Hill (eds) Women's education in developing countries, Johns Hopkins press for the World Bank, Washington D.C. 
Singh H (1983) "Inequality in labour market rewards and education in India: A case study of Delhi”, Indian Economic Review 28 (2) July-Dec, 1983.

Strauss, J and D Thomas (1995) "Human Resources: Empirical modelling of household and family decisions", in Behrman, $\mathrm{J}$ and T N Srinivasan (eds) Handbook of Development Economics, Vol III.

Subbarao, K and L Raney (1995) "Social Gains from Female Education: A Cross-National Study", Economic Development and Cultural Change, 44(1), October 1995, 105-128.

Tilak, J B G (1987) The economics of inequality in education, Sage, New Delhi.

Tilak, J B G (1990) "Education and earnings: Gender differences in India", International Journal of Development Planning Literature, 5 (4), 131-139.

UNDP(1996) "Human Development Report", United Nations Development Programme, New York.

Unni, Jeemol (1995) "Returns to education by gender among wage employees in urban India", Working paper No. 63, Gujarat Institute of Development Research, Ahmedabad.

Vijverberg, Wim (1991) "Measuring Income from family enterprises with household surveys", Living Standards Measurement Study Working Paper No. 84, The World Bank, Washington D.C. 